Article

\title{
Unraveling Aquatic Quality Controls of a Nearly Undisturbed Mediterranean Island (Samothraki, Greece)
}

\author{
Nikolaos T. Skoulikidis*(D), Anastasia Lampou and Sofia Laschou \\ Hellenic Centre for Marine (Institute of Marine Biological Resources \& Inland Waters) 19013 Anavyssos, Attika, \\ Greece; alampou@hcmr.gr (A.L.); sofial@hcmr.gr (S.L.) \\ * Correspondence: nskoul@hcmr.gr
}

Received: 16 December 2019; Accepted: 6 February 2020; Published: 10 February 2020

check for updates

\begin{abstract}
Due to its rough, mountainous relief, Samothraki remains one of the last minimally disturbed islands in the Mediterranean. This paper examines the hydrogeochemical regime of the island's surface waters as it results from geological, morphological, and hydro(geo)logical controls within a frame of minimally disturbed environmental conditions. Shallow, fractured groundwater aquifers, in combination with steep slopes and predominant weathering resistant rocks, bring about flashy stream regimes with remarkably low solute concentrations. Streams and springs revealed hydrochemical similarities. Contrary to streams chiefly draining sedimentary rocks, streams underlined by granite and ophiolite rocks do not respond hydrochemically to geochemical differences. Using ion proportions instead of concentrations, geochemical fingertips of magmatic stream basins were detected. Atmospheric inputs largely affect stream and spring composition, e.g., by $75 \%$ regarding sodium. Only $20 \%$ of dissolved oxygen and $\mathrm{pH}$ variance was assigned to biological activity, while nutrient levels were consistent with the undisturbed conditions of the island, except nitrate. Small mountainous springs and brooks fed by restricted, fractured groundwater aquifers with perennial flow, despite scarce summer rainfalls, may be fueled by cloud and fog condensation. High night-day stream flow differences, high atmospheric humidity predominately occurring during the night, and low stream water travel times point out toward this phenomenon.
\end{abstract}

Keywords: undisturbed; hydrogeochemistry; aquatic quality; geomorphology; hydrology

\section{Introduction}

For millions of years, various natural controls-including tectonic dynamics, weathering, erosion, sedimentation, evaporation, infiltration, flashing, and metabolic and biogeochemical processes-interacting within the watershed, the floodplains, the riparian zone, and the water body itself-determine a natural spatially and temporally changing aquatic composition regime. Only very recently, considering geological time, human multistressors, such as the introduction of organic and inorganic pollutants, hydrogeomorphological alterations, climate and land use changes, invasive species, and pathogens, are causing dramatic structural and functional alterations in aquatic ecosystems.

Attempting to combat the effects of these pressures, the European Union (EU) introduced, 20 years ago, and applied the Water Framework Directive (WFD), a breakthrough legislation aiming at the assessment, conservation, and rehabilitation of aquatic ecosystems. In the philosophy of the WFD, ecological assessment is largely based on the quality comparison between disturbed aquatic ecosystems to similar ones found under undisturbed conditions. Thus, undisturbed or minimally disturbed aquatic ecosystems serve as the baseline for assessing the deviation from natural conditions of disturbed ones in order to facilitate the development of ecological quality ratios, classification 
schemes, and restoration measures. They additionally represent the ultimate reference point to nature itself, enabling scientists to study ecological patterns and processes, per se, as well as natural system responses to climate change, pollution, and introduced species [1,2]. However, the availability of such ecosystems is low (only $8 \%$ of European rivers are termed as high ecological status [3]) and are mainly restricted to mountainous areas. Reference lowland river sections are practically missing [4], whereas small water bodies (commonly known as headwaters, creeks, streams, brooks, and ponds) reveal poor ecological conditions in many parts of Europe, despite their ecological significance [3]. Regarding Mediterranean Europe, the long history of human presence and the intensive water demand [5] created a deficiency in reference conditions [6].

The "natural" composition of streams has been assigned to interactive geological, geomorphological, climatic, and hydrogeological factors [1,7-13]. As a result of increased carbonate rock dissolution, Greek rivers are enriched in solutes compared to European ones [14]; almost half of the variance of chemical data of major rivers was attributed to carbonate rock dissolution, while the remaining was explained by pollution, biological activity, and acid silicate rock weathering [9]. Greek and Balkan rivers belong to three north-south-extending hydrochemical zones, which simultaneously present distinct geological and climatic features $[15,16]$. Samothraki Island belongs to a zone with prevailing acid silicate rocks, minimum precipitation, river basins with high stream densities, narrow and shallow riverbeds, and relative low solute concentrations with high sulphate levels [17].

Samothraki Island remains one of the last minimally disturbed islands in the Mediterranean, including numerous free-flowing streams that remain largely intact along their entire courses $[18,19]$. However, aquatic research on the island is still at its infancy, probably due to the fact that freshwater resources are adequate and mostly undisturbed. Bearing in mind the scarcity of undisturbed freshwater ecosystems and related data in the Mediterranean basin and elsewhere, and acknowledging the gap of knowledge on the state of Samothraki's aquatic resources, this study attempts to provide an overview of the island's stream ecosystems. It particularly (i) focuses on the geomorphological, hydrogeological, and hydrological background driving stream composition; (ii) illustrates and classifies the aquatic quality characteristics of streams and springs; and (iii) attempts to interpret them as they result from various natural factors and processes, as well as human interference. The results of this study may be used as a baseline in supporting ongoing management and sustainability initiatives on the island related to the national river basin management plans, the municipal and regional strategic development plans, and the success of a UNESCO's Man and Biosphere (MAB) Reserve integration process.

\section{Materials and Methods}

\subsection{Study Area}

Samothraki is a small $\left(178 \mathrm{~km}^{2}\right)$ but high $(1611 \mathrm{~m}$ asl $)$ "mountain in the sea", still emerging ( $\sim 2 \mathrm{~mm} / \mathrm{yr}$ [20]), demonstrating the highest peak in the Aegean Sea after the much larger islands of Crete and Euboea. Samothraki has a humid climate with cold winters (between 0 and $3^{\circ} \mathrm{C}$ ), whereas the central mountainous part of the island is marked by harsh winters (below $0{ }^{\circ} \mathrm{C}$ ) [21]. Due to the lack of a meteorological station on the island (until recently), there is a large uncertainty regarding average precipitation. Annual precipitation has been mainly estimated using meteorological data from the Alexandroupolis station, and thus, varies considerably; $507 \mathrm{~mm}$ [21], $605 \mathrm{~mm}$ [22], $772 \mathrm{~mm}$ [23], and $>1000 \mathrm{~mm}$ [24].

Tectonic uplift movements created a rough relief with steep slopes, predominately at the south-southeast part of the island [25], while intense physical weathering and erosion shaped impressive landforms and geomorphic features. The central part of the island is covered by magmatic rocks formed by two consecutive magmatic intrusions: a Late Jurassic ophiolitic (31\% of the island's surface area) and a Miocene granitic one (26\% of the island's surface area). Magmatic rocks are intensively tectonized and eroded. The ophiolitic unit is intruded by dolerite dykes and consists of gabbros, massive basalt flows, and pillow lavas. Small outcrops of the Upper Jurassic-Lower 
Cretaceous clastic metamorphosed sedimentary basement ( $3 \%$ of the island's surface area) are found around Chora (the capital of Samothraki), while Oligocene-Early Miocene volcanic rocks of basaltic to rhyodacitic composition ( $8 \%$ of the island's surface area) are distributed at the east and west boarders of the igneous rocks. Physical weathering, erosion, and clastic deposition created Pliocene-Quaternary sediments (32\% of the island's surface area) that cover mainly the western part of the island. Quaternary deposits located at the peripheral steep parts of the island form scree, talus cones, and alluvial fans and cover the stream valleys [26].

In contrast to the other Aegean islands, Samothraki is rich in fresh waters in the form of springs, perennial and intermittent streams, thermal waters, small coastal wetlands, and lagoons. In total, there are 23 catchments on the island with perennial or intermittent flow (Table 1 ) that cover $56.5 \%$ of the island's surface. Episodic and ephemeral flowing streams drain the remaining parts of the island. A number of streams flow through ravines with impressive multistep waterfalls, commonly followed by small plateaus with long, pooling waters, known as "vathres".

Groundwater is distributed within two types of aquifers: a $66.2 \mathrm{~km}^{2}$ fractured aquifer that covers three-quarters of the island, located within the weathering zone of magmatic rocks (primarily within ophiolites and secondarily within granites), and a $25.6 \mathrm{~km}^{2}$ alluvial one, located at the western part of the island (Figure 1) [21]. The Institute of Geological and Mineralogical Exploration (IGME) [27,28] registered 42 cold and two thermal springs, located in the lowlands and mid-altitudes of Samothraki. Fractured aquifers are extended within valleys and ravines filled up with weathered material (mainly gravel and sand) of these rocks.

Considering environmental, anthropogenic, and aesthetic criteria, landscapes are in a good or favorable conservation condition [29]. Plant biodiversity is high, with 1534 species-among them, 127 aromatic and therapeutic and 18 endemic and range-restricted ones [30,31] — with impressive pristine oak, alder, and riparian plane forest remains. The vast portion of the island is part of the NATURA 2000 Network. Samothraki is a UNESCO Man and Biosphere Reserve candidate [32], whereas the Samothraki Nature Observatory (founded in cooperation between the Municipality of Samothraki and the Hellenic Centre for Marine Research (HCMR)) joined recently the Greek Network of Long-Term Ecosystem Research (LTER-Greece). Finally, mountainous parts of the island belong to the list of geological monuments of national interest [33].

With a low population density $\left(16\right.$ inhabitants $\left./ \mathrm{km}^{2}\right)$ and its main economic activities being livestock breading, fishing, tourism, and agriculture, Samothraki remains largely undisturbed. According to the Corine Land Cover [34], 4.4\% of the island is forests, 35.2\% scrub and/or herbaceous vegetation, $37 \%$ open spaces with little or no vegetation, and $22.4 \%$ is agricultural land. According to data of the Municipality of Samothraki, the total cultivated area covers $16.7 \%$ of the island, and the main cultivations include livestock crops (40.4\%), olive groves (35.1\%), and cereals (19.7\%) [35]. There are, in total, 15 villages and settlements on the island. The majority of them are served by septic tanks, while two (Chora and Lakoma, with 653 and 317 inhabitants, respectively) afford sewage systems that discharge untreated in adjacent streams, threatening their ecological integrity [18]. The construction of wastewater treatment plants and of a sanitary landfill (currently, solid wastes are temporarily transferred to the mainland) and the implementation of recycling are included in the planning strategy of the local and regional authorities. The dominant pressure on Samothraki is considered to be overgrazing [35]; the number of goats and sheep is estimated to be around 45,000 [36]. Despite a recent decline, the animal number still by far exceeds the grazing capacity of the island [37]. Overgrazing, together with woodcutting and wild fires that took place in the past, enhance soil erosion. As a result, despite the existence of impressive terrestrial and riparian forest remains, there are several mountainous areas with sparse or nearly no vegetation, and these bare areas dominate the highlands and the drier eroded valleys of the southwest (Figure 2). Related recent research showed that a large central area of the island is highly vulnerable to erosion and soil loss [38]. 


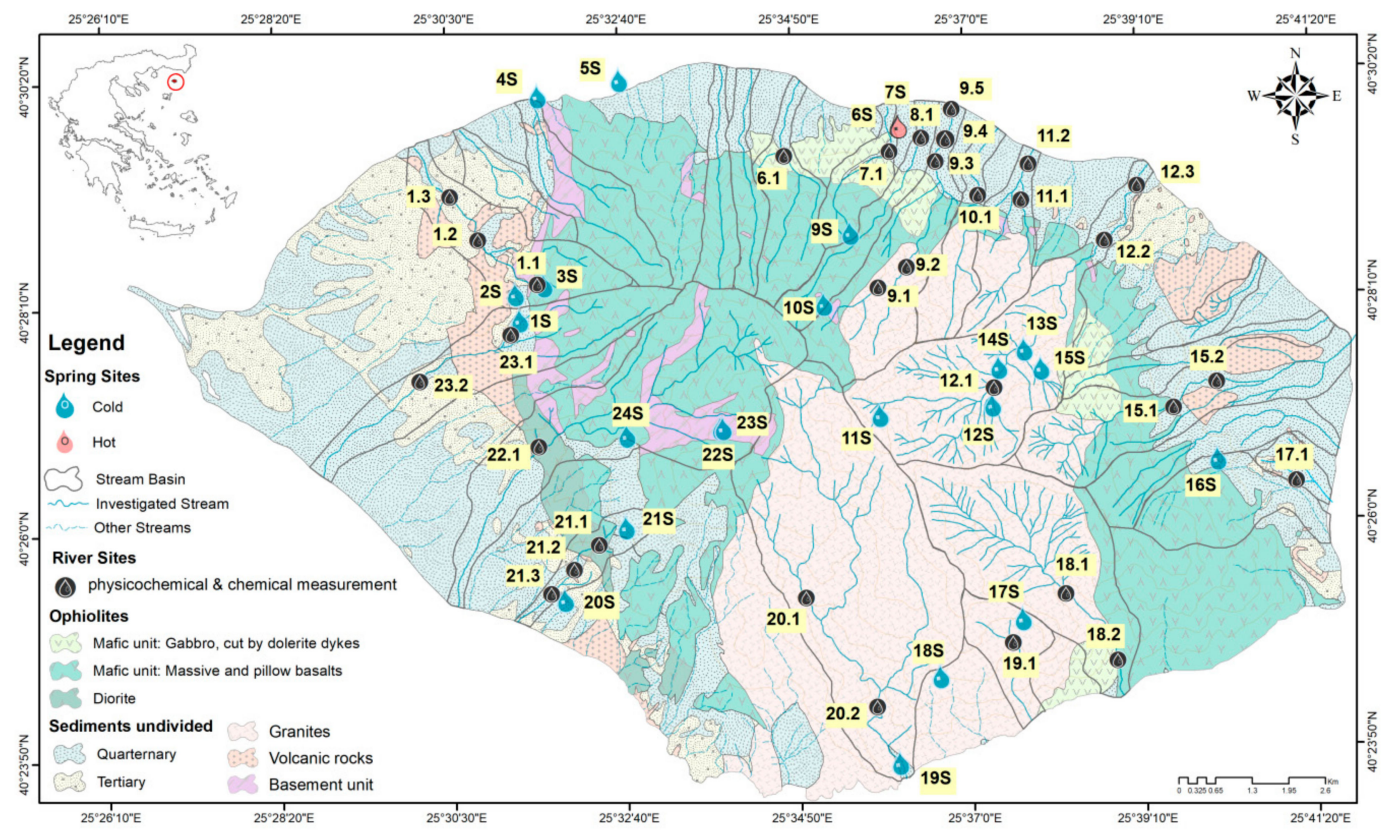

Figure 1. Geological map of Samothraki Island with the examined stream basins and hydrographic network, including spring and stream sampling points. The text in parenthesis refers to the stream or spring basin. Springs: 1S: Ag. Sotiros (Polipoudi), 2S: Katsambas (Katsambas), 3S: Ag. George (Katsambas), 4S: Palaeopoli (Kopsi), 5S: Kariotes, 6S: Therma (a) (Thermiotis), 7S: Therma (b) (Thermiotis), 9S: Mounovrysa (Platia), 10S: Cold Water (Platia), 11S: Louloudi (Fonias), 12S: Karies (Fonias), 13S: Itamos (Fonias), 14S: Fonias (Fonias), 15S: Koufouklio (Fonias), 16S: Kerasia (Lagkadiotis), 17S: Ag. Thekla (Kremasto), 18S: Agelada (Agelada),19S: Vatos (Vatos), 20S: Dafnes, 21S: Pano Panagia (Lakoma), 22S: Sfendami (left) (Xiropotamos), 23S: Sfendami (right) (Xiropotamos), 24S: Panagia Mantalo (Xiropotamos), 1.1: Kastro (Katsambas), 1.2: Chora (Katsambas), 1.3: Chora DS (Katsambas), 6.1: Ano Kariotes (Arapis), 7.1: Therma (Thermiotis), 8.1: Tsivdogiannis (Tsivdogiannis), 9.1: Alonitious (Platia), 9.2: Prinos (Platia), 9.3: Gria Vathra 1 (Platia), 9.4: Gria Vathra 2 (Platia), 9.5: Gria Vathra DS (Platia), 10.1: Grigorakis (Kardelis), 11.1: Varades 1 (Varades), 11.2: Varades 2 (Varades), 12.1: Fonias Springs (Fonias), 12.2: Fonias 1 (Fonias), 12.3: Fonias 2 (Fonias), 15.1: Agkistros 1 (Agkistros), 15.2: Agkistros 2 (Agkistros), 17.1: Lagkadiotis (Lagkadiotis), 18.1: Giali 1 (Giali), 18.2: Giali 2 (Giali), 19.1: Kremasto (Kremasto), 20.1: Karagiannakis (Vatos), 20.2: Vatos (Vatos), 21.1: Kasteli (Lakoma), 21.2: Lakoma 1 (Lakoma), 21.3: Lakoma 2 (Lakoma), 22.1: Xiropotamos 1 (Xiropotamos), 22.2: Xiropotamos 2 (Xiropotamos), 23.1: Alonia (Polipoudi), and 23.2: Polipoudi DS (Polipoudi). 
Table 1. Geomorphological and geological characteristics of stream basins and stream hydromorphometric features.

\begin{tabular}{|c|c|c|c|c|c|c|c|c|c|c|c|c|c|c|c|c|}
\hline River Name & Code $\mathrm{Nr}$ & $H R$ & BA & MA & MS & $S$ & VR & BU & $\mathbf{O}$ & G & $\mathrm{Q}^{1}$ & SO & DD & $\mathbf{R R}$ & TL & SD \\
\hline & & & $\mathrm{km}^{2}$ & $\mathbf{m}$ & o & & & $\%$ & & & $\mathrm{~m}^{3} / \mathrm{s}$ & & $\mathrm{km} / \mathrm{km}^{2}$ & $\mathrm{~h} / \mathrm{L}$ & km & $\mathrm{L} / \mathbf{s}^{*} \mathbf{k m}^{2}$ \\
\hline Fonias & 12 & $\mathrm{P}$ & 9.5 & 794.7 & 21.9 & 8.73 & 0.15 & 0.12 & 5.01 & 85.98 & 0.481 & 4 & 3.92 & 0.16 & 37.4 & 50.5 \\
\hline Platia & 9 & I & 5.4 & 828 & 26 & 12.56 & 0 & 1.11 & 42.41 & 43.92 & 0.14 & 3 & 2.01 & 0.12 & 10.7 & 26.1 \\
\hline Xiropotamos & 22 & I & 12.1 & 720.4 & 24.6 & 20.53 & 0.06 & 18.44 & 59.31 & 1.66 & 0.389 & 3 & 1.8 & 0.14 & 21.8 & 2.9 \\
\hline Agkistos & 15 & $\mathrm{P}$ & 6.5 & 452.4 & 15.5 & 33.92 & 17.33 & 0 & 28 & 20.75 & 0.359 & 4 & 3.32 & 0.15 & 21.7 & 47.2 \\
\hline Polipoudi & 23 & $\mathrm{P}(\mathrm{I})$ & 6 & 330.9 & 13.5 & 44.99 & 15.88 & 8.18 & 30.96 & 0 & 0.018 & 2 & 1.8 & 0.16 & 10.8 & 2.9 \\
\hline Vatos & 20 & I & 16.5 & 781 & 24.6 & 0.55 & 0 & 0.8 & 4.81 & 93.84 & 0.409 & 3 & 1.73 & 0.16 & 28.5 & 24.8 \\
\hline Giali & 18 & $\mathrm{P}(\mathrm{I})$ & 8.9 & 777.9 & 23.4 & 0.48 & 0 & 0 & 19.42 & 80.09 & 0.36 & 4 & 3.3 & 0.2 & 29.5 & 40.3 \\
\hline Kremasto & 19 & $\mathrm{P}$ & 2 & 664.6 & 25 & 0 & 0 & 0 & 0.64 & 99.36 & $0.096^{2}$ & 2 & 1.34 & 0.38 & 2.7 & 12.9 \\
\hline Kardelis & 10 & $\mathrm{P}$ & 2.3 & 642.7 & 27.6 & 26.88 & 0 & 1.26 & 5.19 & 66.66 & 0.047 & 2 & 2.13 & 0.24 & 4.9 & 20.6 \\
\hline Katsambas & 1 & $\mathrm{P}$ & 4.4 & 268 & 16.4 & 41.44 & 24.26 & 4.43 & 29.86 & 0 & 0.049 & 2 & 1.58 & 0.1 & 7.0 & 8.4 \\
\hline Lakoma & 21 & $\mathrm{P}$ & 1.5 & 244.4 & 16.4 & 69.63 & 1.45 & 0 & 28.92 & 0 & 0.024 & 2 & 2.47 & 0.14 & 3.8 & 15.9 \\
\hline Arapis & 6 & I & 2.9 & 604.2 & 24.2 & 12.79 & 0 & 0.23 & 86.98 & 0 & 0.196 & 2 & 2.23 & 0.3 & 6.5 & 67.6 \\
\hline Agas & 4 & I & 1.8 & 617.9 & 26.7 & 25.44 & 0 & 0.35 & 74.21 & 0 & 0.061 & 1 & 2.24 & 0.33 & 4.1 & 33.8 \\
\hline Tsivdogiannis & 8 & I & 2.2 & 649.9 & 21.2 & 21.91 & 0 & 0.33 & 77.76 & 0 & 0.12 & 2 & 2.47 & 0.31 & 5.5 & 53.6 \\
\hline Thermiotis & 2 & $\mathrm{P}$ & 1.7 & 348.9 & 20.4 & 14.93 & 0 & 0 & 85.07 & 0 & 0.052 & 2 & 1.98 & 0.24 & 3.4 & 30.7 \\
\hline Varades & 11 & $\mathrm{P}(\mathrm{I})$ & 2.5 & 394.4 & 17.9 & 30.57 & 0 & 3.64 & 8.26 & 57.52 & 0.063 & 3 & 3.07 & 0.23 & 7.7 & 25.1 \\
\hline Kopsi & 3 & I & 3.4 & 496.1 & 21.9 & 17.32 & 2.63 & 17.36 & 62.69 & 0 & 0.001 & 2 & 2.14 & 0.27 & 7.2 & 0.3 \\
\hline Ano Meria & 14 & I & 2.2 & 336.9 & 15.2 & 57.22 & 8.16 & 0 & 34.62 & 0 & 0.024 & 1 & 2.34 & 0.19 & 5.0 & 11.0 \\
\hline Isomata & 13 & I & 1.1 & 129.8 & 9.6 & 72.61 & 27.39 & 0 & 0 & 0 & 0.057 & 3 & 3.74 & 0.07 & 4.0 & 53.9 \\
\hline Platipotamos & 16 & $\mathrm{P}(\mathrm{I})$ & 3.4 & 464.4 & 18 & 55.69 & 1.15 & 0 & 43.17 & 0 & 0.088 & 2 & 2.5 & 0.23 & 8.5 & 25.7 \\
\hline Lagkadiotis & 17 & $\mathrm{P}(\mathrm{I})$ & 0.8 & 447.4 & 9.8 & 96.58 & 3.42 & 0 & 0 & 0 & 0.016 & 2 & 3.04 & 0.09 & 2.5 & 19.5 \\
\hline Waves & 2 & I & 1.7 & 135 & 22.2 & 73.67 & 7.65 & 10.11 & 8.56 & 0 & 0.002 & 2 & 1.96 & 0.12 & 3.3 & 1.2 \\
\hline Mantzar & 5 & I & 1.7 & 538 & 11 & 30.56 & 0 & 0.66 & 68.78 & 0 & 0.065 & 1 & 2.29 & 0.32 & 4.0 & 37.3 \\
\hline
\end{tabular}

HR: hydrological regime, BA: stream basin area, MA: mean basin altitude, MS: mean basin slope, S: \% of Plio-Quaternary sediments in stream basin, VR: \% of volcanic rocks in stream basin, BU: \% of the basement unit in stream basin, O: \% of ophiolites in stream basin, G: \% of granites in stream basin, Q: discharge, SO: stream order after Strahler, DD: drainage density, intermittent, $\mathrm{P}(\mathrm{I})$ : perennial up to approx. $100 \mathrm{~m}$ before the outflow. ${ }^{2}$ : approximately, since it is difficult to be measured, as the Kremasto stream is falling abruptly into the sea, creating a

180-m-high waterfall. 


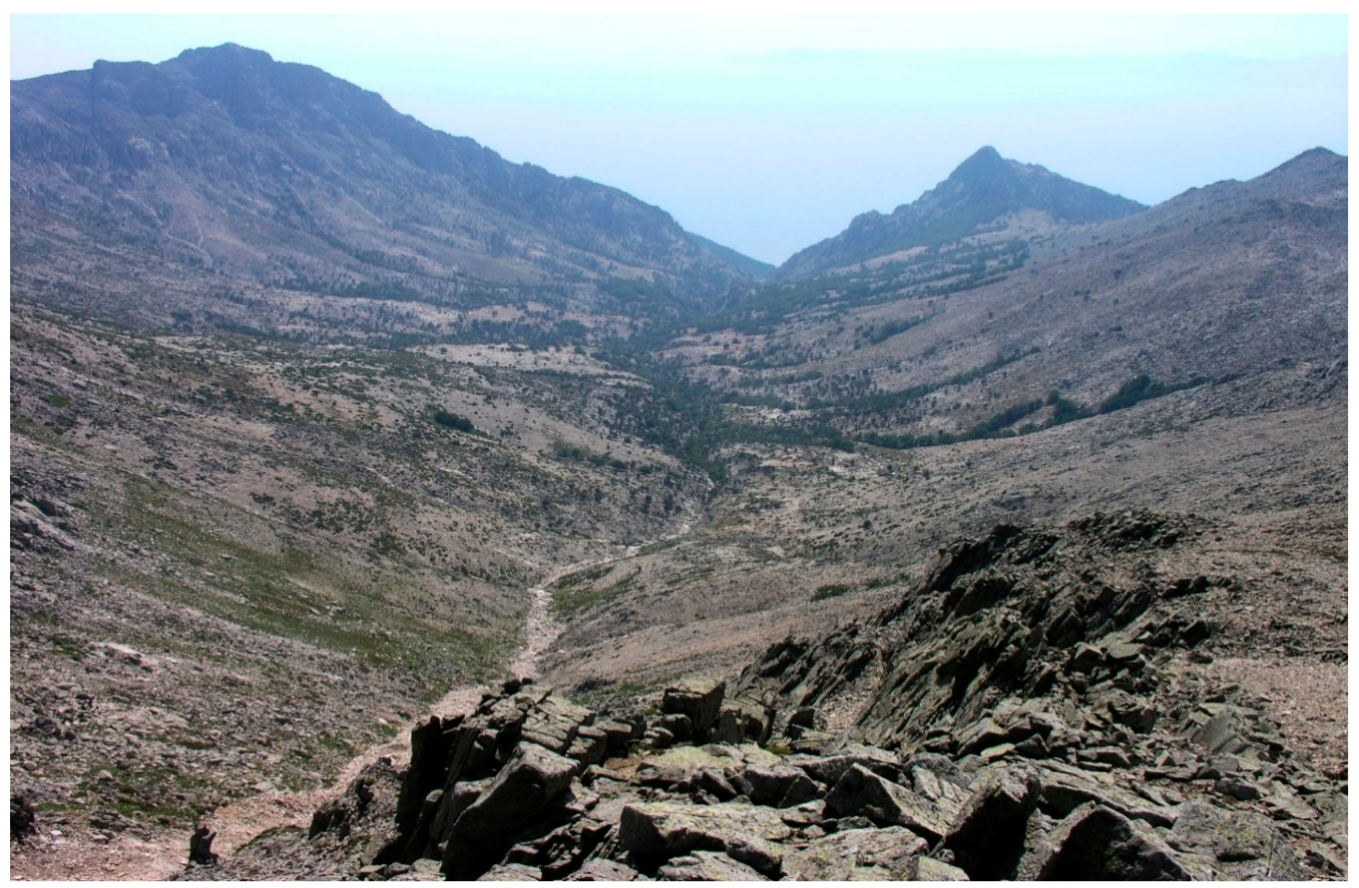

Figure 2. The upstream portion of the Giali stream basin, presenting a bare plate-form granitic plateau with limited regolith cover.

\subsection{Data Collection}

\subsubsection{Field Measurements, Sampling, and Lab Analysis}

In the framework of two European research projects (AQEM: ENVK1-1999-00132 and STAR: ENVK1-CT-2001-00089), a master thesis [38], the National Monitoring Program (2012-2015), and self-funding activities by HCMR, a number of field surveys have been carried out on Samothraki Island aquatic resources focusing on hydrochemical and hydrological aspects. The main campaigns were conducted in summer 2013 and spring 2014. Stream sites 9.3 and 12.3 have been investigated also in summer-winter 2000 and spring 2001, while sites 9.3,9.4, 12.2, 22.1, and 22.2 were additionally sampled in spring and fall 2011. Stream discharge measurements were carried out simultaneously with samplings. In May 2014 and June 2019, all stream outflows have been considered. Finally, springs were sampled ones during 2012-2015.

In total, 16 streams (30 stream sites) were investigated (Figure 1). Streams were studied for discharge; physicochemical parameters; water temperature (WT); conductivity (EC); $\mathrm{pH}$; dissolved oxygen (DO); and chemical parameters, i.e., $\mathrm{Ca}^{2+}, \mathrm{Mg}^{2+}, \mathrm{Na}^{+}, \mathrm{K}^{+}, \mathrm{HCO}_{3}{ }^{-}, \mathrm{CO}_{3}{ }^{2-}, \mathrm{Cl}^{-}, \mathrm{SO}_{4}{ }^{2-}, \mathrm{SiO}_{2}$, water hardness, $\mathrm{NO}_{3}{ }^{-}, \mathrm{NO}_{2}{ }^{-}, \mathrm{NH}_{4}{ }^{+}, \mathrm{PO}_{4}{ }^{3-}$, and total phosphorous (TP), as well as for their habitat composition, depicted from the application of the RIVPACS site protocol [39]. The examined stream basins cover $56 \%$ of the island's surface area. The unexamined area, located mainly at the western and southern parts of the island, is drained by ephemeral or episodic streams. Twenty-one cold and two hot springs have been additionally surveyed for their physicochemical and chemical characteristics (in hot springs, heavy metals were additionally measured). Efforts have been made to access high-altitude cold springs, since they were not included in previous studies by the Institute of Geological and Mineral Exploration (IGME).

Flow and cross-section measurements were applied to determine discharge according to [40]. Riverbed substrate composition was defined visually at the reach scale, using the Wentworth scale [41]. WT, DO, pH, and EC were measured in situ using a flow probe (FP111 Global Water Flow Probe, Global Water, College Station, Texas, USA) and a waterproof portable logging multiparameter meter (HI-98194, Hanna Instruments, Leighton Buzzard, UK). Water samples were collected in polyethylene bottles (previously cleaned with diluted $\mathrm{HCl}$ ), and $1 \mathrm{~mL} / \mathrm{L}$ of $1 \% \mathrm{HgCl}_{2}$ solution was added as a preservative. 
Samples were transferred under freeze in the laboratory; filtered through $0.45 \mu \mathrm{m}$ membrane filters; and analyzed for major ions, silicate, and nutrients.

Major ions were measured by ion chromatography using a Metrohm Ion Chromatographer. Hydrogen carbonate and carbonate were determined by titration with $0.1 \mathrm{~N} \mathrm{HCl}$ and the proper selective electrode using an automatic titrator (TIM 900 Radiometer). Nitrite, ammonium, and orthophosphate were determined photometrically. For higher concentrations (i.e., $\mathrm{N}-\mathrm{NO}_{2}{ }^{-}>0.005 \mathrm{mg} / \mathrm{L}, \mathrm{N}-\mathrm{NH}_{4}{ }^{+}>0.010 \mathrm{mg} / \mathrm{L}$, and $\mathrm{P}_{-} \mathrm{PO}_{4}{ }^{3-}>0.010 \mathrm{mg} / \mathrm{L}$ ), the spectrophotometer MERCK-FARO 300 was used and, for lower ones, the nutrient Bran+Luebbe AutoAnalyzer II and a Perkin-Elmer spectrophotometer. Concerning nitrates, ion chromatography was applied for higher concentrations $\left(\mathrm{N}^{-N}{ }_{3}{ }^{-}>0.023 \mathrm{mg} / \mathrm{L}\right)$, and the automatic nutrient analyzer was used for lower ones. The determination of ammonium was carried out according to the Berthelot reaction following EPA 350.1, APHA 4500-NH3 F, ISO 7150-1, and DIN 38406-5. For low ammonium concentrations ( ${\mathrm{N}-\mathrm{NH}_{4}}^{+}$ $<0.010 \mathrm{mg} / \mathrm{L}$ ), the Koroleff [42] method was applied. The determination of nitrite was performed according to the Griess reaction following EPA 354.1, APHA 4500- $\mathrm{NO}_{2}{ }^{-} \mathrm{B}$, and DIN EN26 777 D10. Phosphate was determined using the phosphomolybdenum blue (PMB) method according to DIN EN 1189 D11, ISO 6878/1, APHA 4500-P E, and EPA 3652 and 3. For the automatic nutrient analyzer, the methodology described by Shinn [43] and Strickland and Parsons [44] was followed for nitrate and nitrite and the methodology of Murphy and Riley [45] for phosphate. For the determination of total phosphorous, organic and inorganic compounds were transformed into phosphates by treatment with an oxidizing agent in a thermoreactor. The treated samples were measured as above for phosphates.

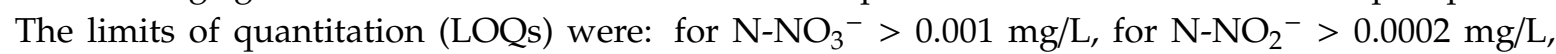
for $\mathrm{P}_{-} \mathrm{PO}_{4}{ }^{3-}>0.001 \mathrm{mg} / \mathrm{L}$, and for $\mathrm{N}^{3-\mathrm{NH}_{4}}{ }^{+}>0.0005 \mathrm{mg} / \mathrm{L}$.

Finally, in order to study hydrometeorological characteristics of Samothraki streams, in September 2018, a meteorological station was placed at an altitude of $800 \mathrm{~m}$ asl in the Fonias stream basin and an automatic water level recorder at the Fonias stream outflow.

\subsubsection{Additional Data and Data Treatment}

Information about each site and its catchment characteristics, i.e., distance from source, stream order, site altitude, stream relief ratio, drainage density, catchment area, mean catchment altitude, and slope; catchment geology; and land use were gathered by applying ArcGIS 10.1 software [46]. Stream relief ratio was calculated as the difference between maximum and minimum stream altitude divided by the stream length. Drainage density was calculated by dividing the total length of all streams in a drainage basin with the total area of the basin.

Spring and stream hydrochemical types were defined according to major cation and anion sequences. For water hardness, the classification after Hem [7], and, for stream solute concentrations, the classification after Skoulikidis et al. [14], were followed. In absence of any significant human pressures, stream physicochemical quality was sufficiently represented by using average dissolved oxygen and nutrient concentration for each stream site. Its assessment was based on the Skoulikidis [47] classification system, using the methodology adopted by the Special Secretariat of Waters (Greek Ministry of Environment and Energy); if the sites were investigated during different years and seasons, the median value for each parameter (i.e., nutrients and dissolved oxygen) was calculated, whereas the physicochemical quality was derived from the average qualities of the individual parameters, according to the WFD implementation prescriptions.

In order to check for statistically significant differences of physicochemical variables, major ions, and nutrients between springs and streams, a Mann-Whitney U test was applied [48], since a number of variables failed to meet normal distribution (checked using the 1-sample Kolmogorov-Smirnov test [49]).

To compare the average chemical composition of Samothraki streams with other Greek running waters, the IMBRIW's (Institute of Marine Biological Resources and Inland Waters, HCMR) database was used for rivers and streams distributed throughout the country [17]. The IMBRIW database currently 
includes 394 stations (129 rivers and streams) regarding physicochemical parameters, 77 stations (60 rivers and streams) with major ion analyses, and, considering nutrients, 774 stations (182 rivers and streams). Normality of data was tested using the 1-sample Kolmogorov-Smirnov test. Since some variables failed to meet the test's criteria, in order to examine similarities or differences in major ion composition of Samothraki streams compared to Greek mainland rivers and island streams, a Kruskal Wallis test was performed. To examine similarities or differences in nutrient concentrations between Samothraki streams and Greek mainland rivers, a Mann-Whitney U test was carried out. Finally, spring water quality was evaluated considering drinking water standards and was compared with the quality of spring bottled waters over Europe using an unpublished brand collection of $\mathrm{N}$. Skoulikidis. A Kruskal-Wallis test to check for significant differences in total dissolved ions (TDI) between Samothraki and European bottled springs was applied, as TDI failed to meet the criteria of the 1-sample Kolmogorov-Smirnov test.

To identify relationships between pair of variables, the Spearman correlation analysis was performed (since part of the data were not normally distributed) for: (a) river basin geological and hydromorphological characteristics; (b) springs regarding physicochemical and hydrochemical parameters and altitude; and (c) stream sites considering the multiyear average of physicochemical and hydrochemical parameters and the river basin environmental characteristics (rock types, morphological features, land uses, etc.) using the Statistical Product and Service Solutions (SPSS) software [50]. To interpret any relationships among major ions and environmental factors, apart from ion concentrations, ion proportions, i.e., their percentage contribution to TDI, and ion rates [1] have been applied. These methods have been considered in order to avoid differing dilution, evaporation [51], and rock weatherability among stream sites examined.

To identify groups of stream, spring, and rainfall waters with similar chemical characteristics, a cluster analysis categorized with Euclidean distance was performed, focusing on the multiyear average of major ion and silicate concentrations. Prior to cluster analysis, the input variables were $\log$ transformed and normalized [52]. An exploratory analysis (SIMPER) was used to detect those variables that contribute in the homogeneity within the cluster groups or in the heterogeneity among the groups. These analyses were carried out using the PRIMER 6 [53].

Focusing on the data of the automatic level recorder, water level measurements were converted to discharge by applying a rating curve. In order to examine if night-day discharge differences were statistically significant, normality and homoscedasticity of data were verified using the 1-sample Kolmogorov-Smirnov test and the Levene's test, respectively [17,54], and an independent samples $t$-test was applied to day and night water-discharge groups for the period 26 August to 24 September 2019, where the water level recorder provided reliable data.

In order to roughly estimate stream water travel time, we focused on the Fonias stream for the summer period, where adequate hydrological data existed. We first calculated average flow velocity (AFV) and average cross-section (ACS) using measurements carried out in summer during 2013-2019 at a site near the outflow (Site 12.3, Figure 1). We then upscaled the resulting values for the entire stream. To upscale the ACS, we assumed that mean stream cross-section is half of the downstream cross-section, as Google Maps images indicated. To upscale stream flow velocity, we multiplied AFV by the ratio between the calculated average stream valley slope (0.142) from ArcGIS software and the measured valley slope at the downstream (0.03) using a methodology developed by Dimitriou and Stavroulaki [55]. We then multiplied the resulting number by 2 to adapt cross-section. Finally, we calculated travel time by dividing the stream's total length $(7.2 \mathrm{~km})$ with the calculated flow velocity.

\section{Results}

\subsection{Hydro(geo)logical and Geomorphological Aspects}

According to the data of the Samothraki meteorological station placed at Chora (90 $\mathrm{m}$ asl), the average precipitation for the period 2008-2016 was $647 \mathrm{~mm}$. However, the total precipitation of 
the island is much higher; for the hydrological year 2018-2019, the HCMR meteorological station measured three times more precipitation $(1582 \mathrm{~mm})$ than the lowland one $(584 \mathrm{~mm})$. In addition, $32 \%$ of the meteorological measurements (30-min steps) of the mountainous station revealed $>95 \%$ air humidity. However, during summer, the mountains and the lowlands receive similar low rainfall; the total rainfall from June to September 2019 was only $62 \mathrm{~mm}$ at $800 \mathrm{~m}$ asl and $52 \mathrm{~mm}$ at $90 \mathrm{~m}$ asl.

During our field trips, it has been observed that numerous fractured-type headwater springs carried water throughout the year. It has been additionally observed that spring and stream discharge was higher during the night. This evidence has been also confirmed by local shepherds who state that "in the night, springs are dripping". These observations were justified by the measurements of the automatic water level recorder for the period 26 August-24 September 2019. The data showed clear diurnal variations, with higher water levels in the night (Figure 3). Nighttime water discharge (average: $0.53 \mathrm{~m}^{3} / \mathrm{s} \pm 0.11 \mathrm{~m}^{3} / \mathrm{s}$ ) was significantly higher than daytime values (average: $0.30 \mathrm{~m}^{3} / \mathrm{s} \pm$ $\left.0.15 \mathrm{~m}^{3} / \mathrm{s}\right)(p<0.001)$. On the average, discharge increased during the night by $0.226 \mathrm{~m}^{3} / \mathrm{s}$. The average daytime discharge calculated from the data of the water level recorder is consistent with manual summer discharge estimations calculated from flow and cross-section measurements. Finally, during the same period (26 August-24 September 2019), 20\% of the meteorological air humidity data exceeded $95 \%$. The vast majority (91\%) of $>95 \%$ humidity measurements occurred during nighttime.

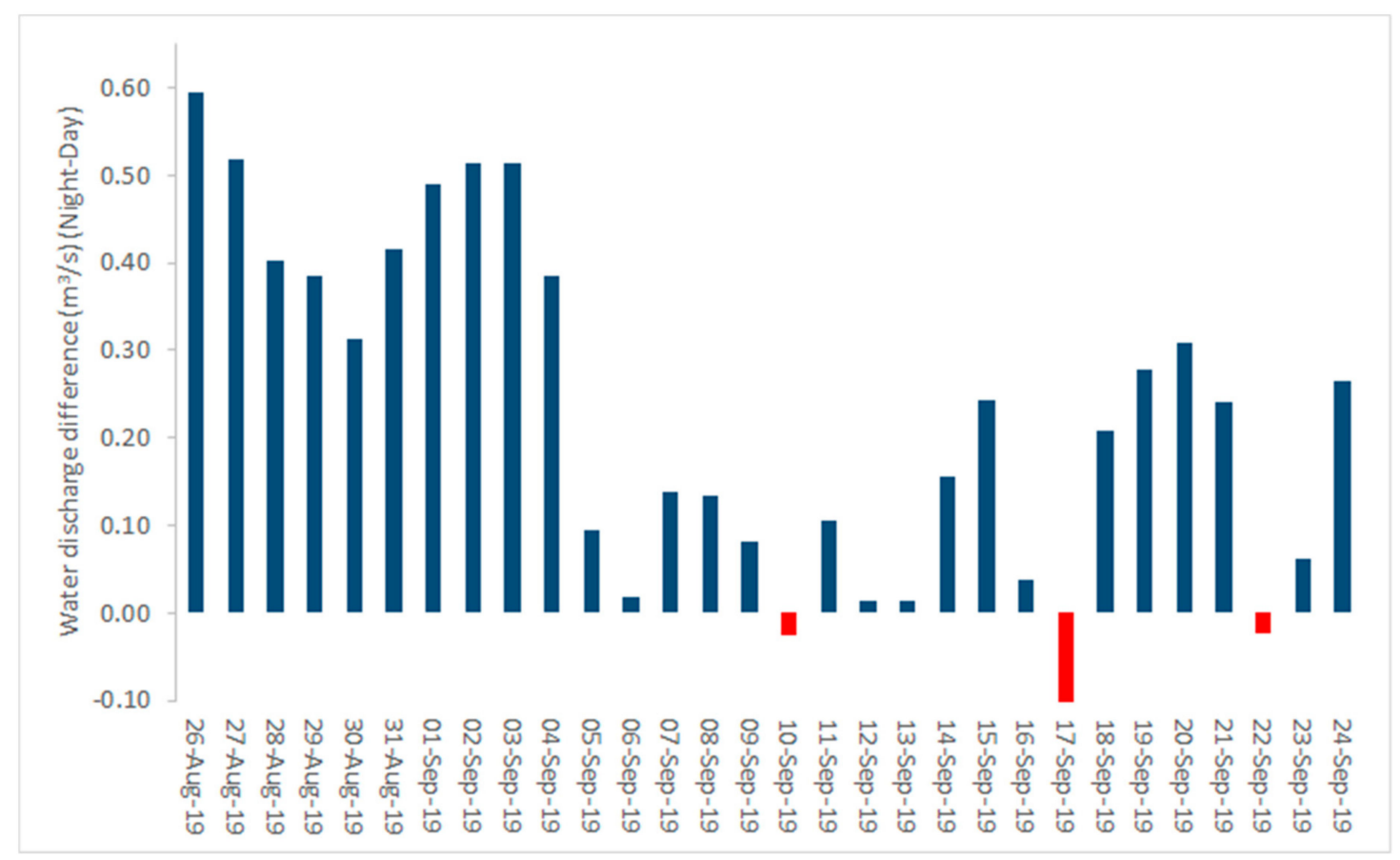

Figure 3. Diurnal water discharge differences in the Fonias stream for the dry period from 26 August to 24 September 2019. Positive values indicate higher water levels during the night (4:00 a.m.-7:00 a.m.) and negative values indicate higher water levels during the day (12:00 p.m.-4:00 p.m.).

Running waters may be termed as streams since they have a low order and belong to minor basins. The majority of stream basins are termed very small $\left(<10 \mathrm{~km}^{2}\right)$, and only two of them (Vatos and Xiropotamos) are termed small $\left(10-100 \mathrm{~km}^{2}\right)$. The majority of the hydrographic network of Samothraki is developed on weathering resistant rocks (that cover $59 \%$ of the basins examined), and only one-third of the basins examined are covered by recent Plio-Quaternary sediment formations. Stream basins with predominance in recent sediments are mainly developed at the western part of the island. This is also the case for a few minor streams mainly located at the eastern part of the island (Figure 1). At their outflows, some streams, such as Agkistros, Fonias, Polypoudi, Xiropotamos, Vatos, and Giali, form small deltas with small coastal wetlands. 
The mean altitude of all stream basins examined reaches $504 \mathrm{~m}$. The vast majority of stream basins present a mid-altitude (200-800 m), and only two of them (Isomata and Waves, Figure 1) are termed lowland $\left(<200 \mathrm{~m}\right.$ ). Average stream basin slope is $19.6^{\circ}$ or $34.4 \%$ (median $21.2^{\circ}$ or $38.8 \%$ ), ranging between $9.6^{\circ}(16.9 \%)$ and $27.6^{\circ}(52.3 \%)$. As granites cover the steep, central peaks of the island, stream basin altitude and slope are positively correlated with the granite percentage in stream basins (Table 2). Average stream relief ratio is 0.20 (median 0.19) and ranges between 0.07 and 0.38 . Maximum relief ratio presents Kremasto, which ends up in the sea by forming a 180-m waterfall. Stream basins where recent sedimentary rocks prevail are marked by low altitude and slope and a low relief ratio (Table 2).

The majority of the catchments are particularly elongated and show a parallel drainage pattern with few tributaries (Figure 1). Average drainage density in these catchments is $2.25 \mathrm{~km}^{-1}$ and average stream order 2.16. The upstream portions of a number of larger stream basins, such as the Fonias, Giali, and Agkistros, present a plate-form basin area (Figure 1). There, much of the landscape is a bare granite plateau with limited regolith cover (Figure 2). In these catchments, numerous small springs with low aquifer capacity and small brooks contribute to the streams' hydrograph, developing a dendritic pattern with maximum drainage density (average $3.52 \mathrm{~km}^{-1}$ ), stream order (average four), and stream length. Thus, basins with high granite portions are large highland with steep slopes and are drained by high-order streams (Table 2). As these streams flow downstream, their basin area narrows, drainage density lowers substantially, and the streams incise in the bedrock. On the contrary, sedimentary stream basins are small lowland with smooth slopes (Table 2).

Granite landscapes are marked by intensively deformed inselbergs, domes, and peaks, especially at high altitudes. Both granitic and ophiolitic rocks are subject to intense physical weathering and erosion, resulting to the development of extensive alluvial fans [26]. Commonly, large angular boulders are being detached from the parent rock and roll along the mountain slopes getting gradually rounded. As a result of high stream gradients and energy, rock debris, including large boulders, is transferred towards the stream mouths. Thus, coastal areas are dominated by cobbles and pebbles, whereas large boulders may be also present (e.g., at Giali and Vatos outflows). The majority of streams flowing through massive magmatic rocks can be termed bedrock streams [56]; their bed and banks are largely composed of in-place bedrock, and only thin, patchy, and temporary alluvial cover composed by boulders, cobbles, and gravel and small amounts of sand and clay.

Using spring and stream discharge measurements from HCMR, IGME, and the Public Power Corporation (PPC), Skoulikidis et al. [57] estimated the total mean annual runoff of the island at $2.08 \mathrm{~m}^{3} / \mathrm{s}$. In May 2014, the total stream runoff was estimated at $3.12 \mathrm{~m}^{3} / \mathrm{s}$. This number is an order of magnitude higher than the total stream runoff measured in June $2019\left(0.30 \mathrm{~m}^{3} / \mathrm{s}\right)$. This result is not due to hydrological differences between these particular years; the monthly variation pattern of precipitation of both years was similar, while the total precipitation of the period January-May for both years was the same (300.2 $\mathrm{mm}$ for 2014 and 300.6 for 2019). Stream discharge correlated positively with mean basin altitude and the granite percentage within stream basins and stream order and negatively with the percentage of Plio-Quaternary sediments in the basins (Table 2). Highest discharge presented the Fonias, Vatos, Giali, and Agkistros streams (Table 1). According to monthly measurements by PPC, the long-term (1986-1991) average runoffs of the Fonias and Xiropotamos were estimated at 0.26 and $0.21 \mathrm{~m}^{3} / \mathrm{s}$, respectively. It should be noted that the period 1989-1991 was particularly dry, and thus, the mean annual discharge of these rivers is underestimated. The resulting specific discharge of the Fonias basin $\left(27.5 \mathrm{Ls}^{-1} \mathrm{~km}^{-2}\right)$ is one of the highest in Greece, even higher than in river basins placed in western Greece, where precipitation is the maximum [17]. On the contrary, the specific discharge of Xiropotamos was much less $\left(17.3 \mathrm{Ls}^{-1} \mathrm{~km}^{-2}\right)$. Using the total mean annual runoff estimation [43] for the examined basins (total area $99.7 \mathrm{~km}^{2}$ ), the resulting average specific discharge was $20.35 \mathrm{ls}^{-1} \mathrm{~km}^{-2}$. Finally, the travel time of water from the sources to the outflow of the Fonias stream, during the summer period, was roughly estimated at $48^{\prime}$. 
Table 2. Summarized results of cross-correlation analysis for hydromorphological features of the 23 Samothraki Island stream basins.

\begin{tabular}{|c|c|c|c|c|c|c|c|c|c|}
\hline & Basin Area & $\begin{array}{l}\text { Mean Basin } \\
\text { Altitude }\end{array}$ & $\begin{array}{l}\text { Mean Basin } \\
\text { Slope }\end{array}$ & Discharge & $\%$ Granites & $\%$ Ophiolites & \% Sediments & $\begin{array}{l}\text { Total Stream } \\
\text { Length }\end{array}$ & Stream Order \\
\hline Basin area & & $0.593 * *$ & & & $0.549 *$ & & $-0.541 *$ & $0.950 * *$ & $0.582 * *$ \\
\hline Mean basin altitude & $0.593 * *$ & & $0.674^{* *}$ & $0.669^{* *}$ & $0.690 * *$ & & $-0.833^{* *}$ & $0.521 *$ & \\
\hline Mean basin slope & & $0.674^{* *}$ & & & $0.527^{*}$ & & $-0.683^{* *}$ & & \\
\hline Relief ratio & & & & & & $0.451 *$ & $-0.492 *$ & & $-0.426 *$ \\
\hline$\%$ Granites & $0.549 *$ & $0.690 * *$ & $0.527 *$ & $0.597^{* *}$ & & $-0.516 *$ & $-0.647^{* *}$ & $0.464 *$ & $0.647^{* *}$ \\
\hline$\%$ Ophiolites & & & & & $-0.516^{*}$ & & & & $-0.440 *$ \\
\hline$\%$ Sediments & $-0.541 *$ & $-0.833 * *$ & $-0.683 * *$ & $-0.644^{* *}$ & $-0.647^{* *}$ & & & $-0.483 *$ & \\
\hline Drainage density & & & $-0.427 *$ & & & & & & \\
\hline Discharge & $0.484 *$ & $0.669^{* *}$ & & & $0.597 * *$ & & $-0.644^{* *}$ & $0.503 *$ & $0.517^{*}$ \\
\hline Stream order & $0.582 * *$ & & & $0.517 *$ & $0.647^{* *}$ & $-0.440 *$ & & $0.638 * *$ & \\
\hline
\end{tabular}

${ }^{* *}$ Correlation is significant at the 0.01 level. ${ }^{*}$ Correlation is significant at the 0.05 level. 


\subsection{Hydrogeochemistry}

\subsubsection{Hydrochemical Characteristics of Springs and Streams}

In springs and streams, the sum of cations and anions were highly positively correlated $\left(r^{2}=0.993\right)$. The absolute mean error of ion balance was $5.05 \%$ for springs and $5.89 \%$ for streams, which is acceptable for the purposes of this study $[7,14,58]$.

The aquatic composition of springs and stream sites, as well as environmental features of stream site basins and reaches are presented in Table $3 a, b$ and Table $4 a, b$, respectively. Table $4 b$ additionally illustrates the quality status of nutrients in Samothraki streams according to a classification system developed for Greek rivers and streams [14,47].

When comparing average TDI of Samothraki springs with bottled springs of several European countries, it appears that the springs of the island were revealed of the lowest mineralization in Europe (Figure S1), and this differentiation was statistically significant for 16 out of 23 countries $(p<0.01)$. Thermal springs revealed an average WT of $42.3^{\circ} \mathrm{C}$, an average EC of $18 \mathrm{mS} / \mathrm{cm}$, and an average TDI of about $9.95 \mathrm{~g} / \mathrm{L}$, of which, $8.13 \mathrm{~g} / \mathrm{L}$ was represented by sodium and chloride, indicating mixing with seawater. Thermal springs, which are commonly used for curative drinking, exceeded drinking water quality standards regarding manganese.

Streams presented lower mineralization (TDI: $p<0.01)$ and $\mathrm{pH}(p<0.01)$ compared to Greek mainland and island rivers and streams (Table 5). As for most islands, Samothraki streams were enriched with chloride and silicate compared to the mainland (both at $p<0.01$ ). They revealed, however, lower ion concentrations than other islands ( $p<0.01$ to $<0.05$, depending from the ion). Nutrient ratios between Greek rivers and Samothraki streams were high, particularly regarding nitrite, ammonium and phosphate (Table 6).

Regarding the levels of physicochemical variables, major ions, and nutrients, springs and streams in Samothraki were remarkably similar; only WT and ammonium demonstrated statistically justified differences $(p<0.001)$, whereas springs presented lower WT and higher ammonium concentrations compared to streams.

Springs belong to two distinct hydrochemical types (Table 7): the calcium hydrogen carbonate type (14 springs) and the sodium type ( 9 springs). Four calcium hydrogen carbonate subtypes are represented; of which, the most common one was the $\mathrm{Ca}^{2+}>\mathrm{Na}^{+}>\mathrm{Mg}^{2+}>\mathrm{K}^{+}-\mathrm{HCO}_{3}{ }^{-}>\mathrm{Cl}^{-}$ $>\mathrm{SO}_{4}{ }^{2-}$ (seven springs). Most common sodium subtypes were the sodium hydrogen carbonate ones (six springs). Thermal springs fit to a sodium sulphate geothermal subtype.

Compared to springs, the steam hydrochemical composition was more homogenous; 29 out of 30 stream sites belong to the four aforementioned calcium hydrogen carbonate hydrochemical subtypes (Table 7). In particular, 21 stream sites (70\%) fit in the $\mathrm{Ca}^{2+}>\mathrm{Na}^{+}>\mathrm{Mg}^{2+}>\mathrm{K}^{+}-\mathrm{HCO}_{3}{ }^{-}>\mathrm{Cl}^{-}>\mathrm{SO}_{4}{ }^{2-}$ subtype. In this subtype belong also the two rain events. One stream (Kremasto) differed significantly from all others, as it fits to an uncommon sodium chloride type $\left(\mathrm{Na}^{+}>\mathrm{Ca}^{2+}>\mathrm{Mg}^{2+}>\mathrm{K}^{+}-\mathrm{Cl}^{-}>\right.$ $\mathrm{HCO}_{3}{ }^{-}>\mathrm{SO}_{4}{ }^{2-}$ ). 
Table 3. (a) Coordinates, altitude, and date of sampling of springs and rain events and prevailing geological formations in spring aquifers. For abbreviations, see Table 1. (b) Chemical-physicochemical parameters of springs and rain.

(a)

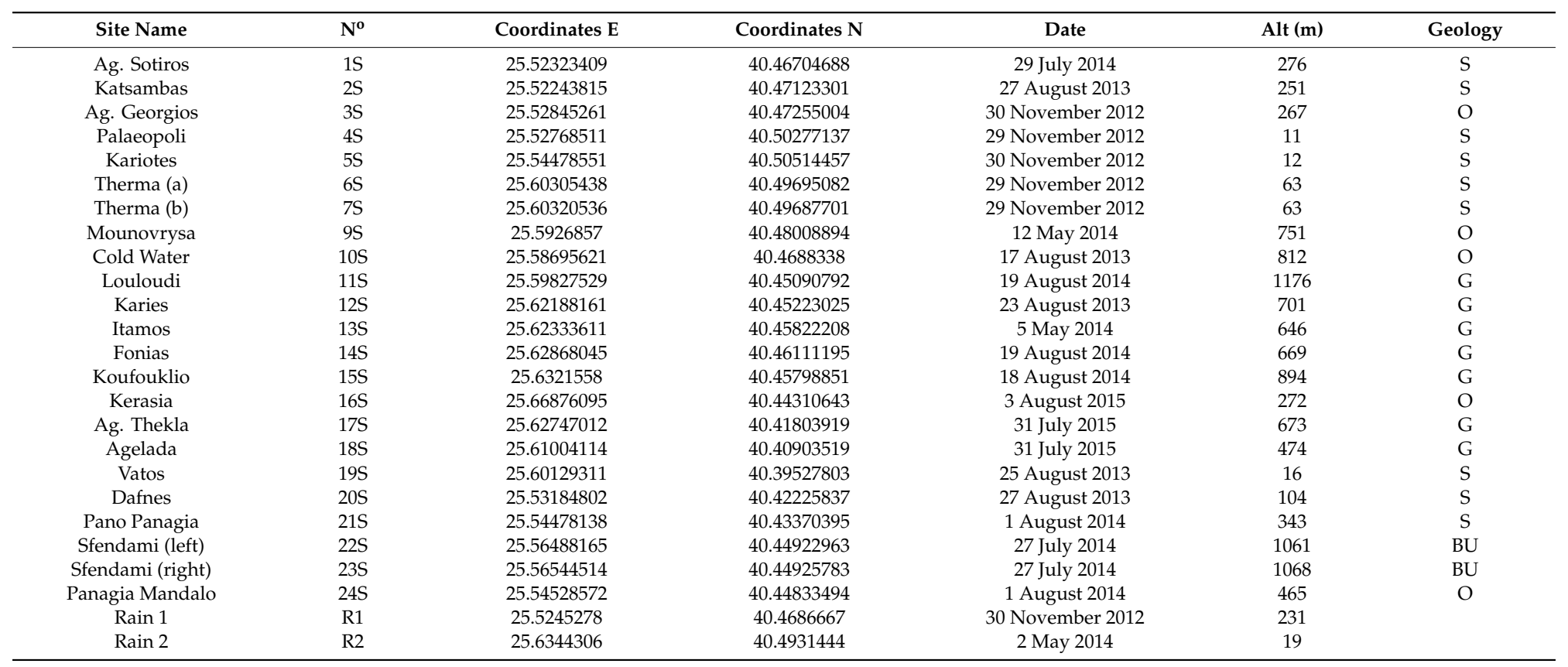


Table 3. Cont.

$(\mathbf{b})$

\begin{tabular}{|c|c|c|c|c|c|c|c|c|c|c|c|c|c|c|c|c|c|c|c|}
\hline Code & WT & $\mathrm{pH}$ & EC & DO & $\mathrm{Ca}$ & Mg & $\mathrm{Na}$ & K & $\mathrm{HCO}_{3}$ & $\mathrm{SO}_{4}$ & $\mathrm{Cl}$ & $\mathrm{SiO}_{2}$ & TDI & TH & $\mathrm{N}-\mathrm{NO}_{3}$ & $\mathrm{~N}-\mathrm{NO}_{2}$ & $\mathrm{~N}-\mathrm{NH}_{4}$ & $\mathrm{P}^{-\mathrm{PO}_{4}}$ & TP \\
\hline & ${ }^{\circ} \mathrm{C}$ & & $\mu \mathrm{s} / \mathrm{cm}$ & \multicolumn{10}{|c|}{$\mathrm{mg} / \mathrm{L}$} & $\begin{array}{c}\mathrm{mg} / \mathrm{L} \\
\mathrm{CaCO}_{3}\end{array}$ & & & $\mathrm{mg} / \mathrm{L}$ & & \\
\hline $1 \mathrm{~S}$ & 15 & 6.85 & 233 & 8 & 39.97 & 4.91 & 8.48 & 0.46 & 124.93 & 11.92 & 11.23 & 11.18 & 213.08 & 119.92 & 1.696 & 0.002 & 0.019 & 0.005 & 0.014 \\
\hline $2 S$ & 16.8 & 8.6 & 110 & 7.7 & 34.60 & 5.07 & 8.67 & 0.36 & 110.90 & 12.45 & 11.05 & 10.94 & 194.04 & 107.18 & 1.680 & 0.003 & 0.005 & 0.006 & 0.016 \\
\hline $3 S$ & 15.5 & 8.44 & 262 & 8.24 & 44.29 & 3.29 & 8.28 & 0.42 & 135.05 & 9.33 & 13.71 & 9.24 & 223.61 & 124.04 & 2.226 & 0.002 & 0.016 & 0.005 & 0.005 \\
\hline $4 S$ & 16.4 & 9.11 & 222 & 4.95 & 33.38 & 3.47 & 89.65 & 11.54 & 96.26 & 15.96 & 140.66 & 11.23 & 402.15 & 97.56 & 1.673 & 0.002 & 0.012 & 0.029 & 0.038 \\
\hline $5 S$ & 16.7 & 8.28 & 267 & 7.2 & 36.47 & 6.35 & 10.24 & 0.47 & 122.49 & 15.12 & 14.6 & 15.12 & 220.86 & 117.11 & 1.208 & 0.002 & 0.022 & 0.005 & 0.005 \\
\hline $6 \mathrm{~S}$ & 41.8 & 6.63 & 19000 & 2.1 & 768.41 & 76.61 & 3538.2 & 478.3 & 408.46 & 77.37 & 4385 & 74.4 & 9806.65 & 2232.30 & 0.045 & 0.002 & 8.042 & 0.029 & 0.032 \\
\hline $7 \mathrm{~S}$ & 42.8 & 6.62 & 17000 & 4.9 & 645.96 & 37.25 & 4042.1 & 553 & 405.77 & 23.87 & 4299 & 87.6 & 10094.75 & 1764.89 & 0.045 & 0.002 & 7.117 & 0.026 & 0.029 \\
\hline $9 \mathrm{~S}$ & 12.5 & 7.58 & 45 & 10.46 & 7.58 & 1.44 & 4.54 & 0.64 & 32.02 & 4.78 & 5.1 & 7.89 & 63.99 & 24.84 & 0.420 & 0.001 & 0.005 & 0.013 & \\
\hline $10 \mathrm{~S}$ & 15 & 7.9 & 48 & 8.2 & 7.28 & 1.09 & 5.07 & 0.72 & 24.16 & 7.73 & 5.42 & 6.92 & 58.39 & 22.65 & 0.662 & 0.001 & 0.005 & 0.003 & 0.005 \\
\hline $11 \mathrm{~S}$ & 15.4 & 7.80 & 54 & 9.3 & 12.39 & 1.56 & 6.68 & 2.52 & 44.47 & 13.93 & 15.26 & 11.32 & 130.80 & 37.33 & 0.763 & 0.002 & 0.040 & 0.062 & 0.085 \\
\hline $12 \mathrm{~S}$ & 17.4 & 7.8 & 35 & 8.9 & 7.83 & 1.32 & 6.82 & 0.1 & 28.12 & 4.57 & 7.78 & 11.56 & 68.10 & 24.97 & 0.287 & 0.005 & 0.033 & 0.002 & 0.005 \\
\hline $13 \mathrm{~S}$ & 11.5 & 5.99 & 37 & 7.81 & 3.34 & 0.90 & 6.08 & 0.56 & 18.36 & 2.89 & 6.55 & 12.96 & 51.64 & 12.04 & 0.639 & 0.000 & 0.013 & 0.010 & 0.022 \\
\hline $14 \mathrm{~S}$ & 17 & 7.91 & & 8.12 & 4.29 & 1 & 5.16 & 0.3 & 21.35 & 2.82 & 6.35 & 9.38 & 50.65 & 14.82 & 0.079 & 0.002 & 0.036 & 0.005 & 0.016 \\
\hline $15 \mathrm{~S}$ & 15.3 & 7.03 & 123 & 9.2 & 40.38 & 4.94 & 8.55 & 0.49 & 133.47 & 12.07 & 8.09 & 11.22 & 219.21 & 121.07 & 1.565 & 0.002 & 0.019 & 0.005 & 0.027 \\
\hline $16 \mathrm{~S}$ & 11.2 & 8.03 & 170 & 10.61 & 25.73 & 5.63 & 30.47 & 1.64 & 84.06 & 17.66 & 60.79 & 10.41 & 236.39 & 87.35 & 0.912 & 0.000 & 0.013 & 0.007 & 0.071 \\
\hline $17 \mathrm{~S}$ & 13.8 & 6.97 & 88 & 9.68 & 9.59 & 2.06 & 7.61 & 1.1 & 30.38 & 8.67 & 11.83 & 17 & 88.24 & 32.40 & 1.366 & 0.001 & 0.011 & 0.023 & 0.046 \\
\hline $18 \mathrm{~S}$ & 21.1 & 7.41 & 130 & 6.44 & 4.99 & 2.07 & 18.05 & 0.76 & 26.66 & 13.34 & 19.07 & 40.92 & 125.86 & 20.96 & 0.095 & 0.001 & 0.025 & 0.065 & 0.076 \\
\hline $19 \mathrm{~S}$ & 17 & 7.6 & 54 & 9.2 & 17.03 & 3.78 & 14.46 & 1.84 & 62.46 & 15.59 & 16.86 & 13.58 & 145.60 & 58.04 & 0.585 & 0.000 & 0.022 & 0.023 & 0.043 \\
\hline $20 \mathrm{~S}$ & 17 & 7.8 & 130 & 7.2 & 104.95 & 26.72 & 38.94 & 0.088 & 372.10 & 72.87 & 51.51 & 17.54 & 684.72 & & 8.484 & 0.001 & 0.005 & 0.001 & 0.005 \\
\hline $21 \mathrm{~S}$ & 15.4 & 6.36 & 144 & 9.55 & 16.91 & 3.64 & 9.07 & 1.21 & 63.93 & 14.19 & 9.38 & 14.4 & 132.73 & 57.16 & 1.734 & 0.002 & 0.014 & 0.013 & 0.047 \\
\hline $22 \mathrm{~S}$ & 8.5 & 5.97 & 67 & 10.74 & 5.31 & 2.56 & 7.07 & 0.7 & 19.70 & 18.42 & 5.05 & 13.78 & 72.59 & 23.78 & 0.589 & 0.002 & 0.030 & 0.013 & 0.036 \\
\hline $23 S$ & 8.5 & 6 & 65 & 10.6 & 5.18 & 2.43 & 4.95 & 0.57 & 17.75 & 16 & 4.31 & 13.34 & 64.53 & 22.92 & 0.598 & 0.002 & 0.017 & 0.026 & 0.054 \\
\hline $24 \mathrm{~S}$ & 15.1 & 6.43 & 133 & 8.93 & 20.75 & 2.17 & 6.7 & 0.69 & 63.26 & 12.41 & 7.97 & 10.28 & 124.23 & 60.70 & 1.134 & 0.002 & 0.019 & 0.016 & 0.032 \\
\hline R1 & & & 80 & & 6.16 & 0.937 & 3.42 & 1.5 & 21.47 & 2.34 & 6.1 & 0.64 & & & & & & & \\
\hline $\mathrm{R} 2$ & & & & & 2.29 & 0.3 & 1.19 & 0.18 & 6.65 & 2.03 & 1.58 & 0.66 & & 6.95 & 0.271 & 0.002 & 0.293 & 0.040 & 0.071 \\
\hline AS * & 14.7 & 7.31 & 115 & 8.89 & 18.1 & 2.96 & 9.31 & 0.699 & 61.24 & 11.26 & 12.65 & 13.23 & 130.76 & 57.33 & 0.96 & 0.002 & 0.020 & 0.017 & 0.035 \\
\hline $\mathbf{A R}$ & & & 80 & & 4.225 & 0.62 & 2.305 & 0.84 & 14.06 & 2.18 & 3.84 & 0.65 & & 6.95 & 0.271 & 0.002 & 0.293 & 0.040 & 0.071 \\
\hline
\end{tabular}

AS: spring average and AR: rain average. * The measurements of Dafnes, Palaiopoli, and Thermal springs were considered outliers and were not included in the average calculation. WT: water temperature, EC: conductivity, DO: dissolved oxygen, TDI: total dissolved ions, and TH: total hardness. 
Table 4. (a) Portion of different rock types within stream site basins, and portion of different habitat types within stream site reaches (DS: downstream). (b) Average of chemical-physicochemical parameters of streams.

(a)

\begin{tabular}{|c|c|c|c|c|c|c|c|c|c|c|c|c|c|c|}
\hline River Name & Site Name & Code on Map & Coordinates & Coordinates & Ophiolites & Granites & Sediments & Bedrock & Boulder & Cobble & Gravel & Coarse-Sand & Sand & Clay \\
\hline & & & $E$ & $\mathbf{N}$ & $(\%)$ & (\%) & (\%) & $(\%)$ & $(\%)$ & $(\%)$ & $(\%)$ & (\%) & $(\%)$ & $(\%)$ \\
\hline Katsambas & Kastro & 1.1 & 25.527288 & 40.473208 & 99.4 & 0 & 0.6 & 0 & 20 & 40 & 10 & 20 & 10 & 0 \\
\hline Katsambas & Chora & 1.2 & 25.518756 & 40.480732 & 43.6 & 0 & 56.4 & 0 & 20 & 40 & 10 & 0 & 0 & 30 \\
\hline Katsambas & Chora DS & 1.3 & 25.508854 & 40.486996 & 44.3 & 0 & 55.7 & 0 & 10 & 10 & 30 & 0 & 20 & 30 \\
\hline Arapis & Ano Kariotes & 6.1 & 25.581744 & 40.489643 & 99.7 & 0 & 0.3 & 10 & 40 & 30 & 10 & 10 & 0 & 0 \\
\hline Thermiotis & Therma & 7.1 & 25.602799 & 40.493728 & 92.3 & 0 & 7.7 & 0 & 0 & 70 & 10 & 10 & 10 & 0 \\
\hline Tsivdogiannis & Tsivdogiannis & 8.1 & 25.609368 & 40.496399 & 86.3 & 0 & 13.7 & 5 & 5 & 60 & 20 & 10 & 0 & 0 \\
\hline Platia & Alonitious & 9.1 & 25.598739 & 40.470970 & 84.7 & 10 & 5.3 & 0 & 10 & 60 & 20 & 10 & 0 & 0 \\
\hline Platia & Prinos & 9.2 & 25.603849 & 40.474733 & 49.5 & 48.8 & 1.7 & 0 & 10 & 60 & 20 & 10 & 0 & 0 \\
\hline Platia & Gria Vathra 1 & 9.3 & 25.611303 & 40.492521 & 59.8 & 31.7 & 8.5 & 0 & 80 & 10 & 0 & 5 & 5 & 0 \\
\hline Platia & Gria Vathra 2 & 9.4 & 25.614717 & 40.496942 & 56.2 & 29.8 & 14 & 0 & 70 & 20 & 0 & 5 & 5 & 0 \\
\hline Platia & GriaVathra DS & 9.5 & 25.615808 & 40.500029 & 54.3 & 29.7 & 16 & 0 & 70 & 20 & 5 & 5 & 0 & 0 \\
\hline Kardelis & Grigorakis & 10.1 & 25.619182 & 40.486021 & 14.4 & 80.1 & 5.5 & 0 & 10 & 30 & 20 & 10 & 30 & 0 \\
\hline Varades & Varades 1 & 11.1 & 25.631055 & 40.492499 & 15.4 & 80.7 & 3.9 & 0 & 70 & 15 & 10 & 0 & 5 & 0 \\
\hline Varades & Varades 2 & 11.2 & 25.629748 & 40.490524 & 14.8 & 54.6 & 30.6 & 0 & 5 & 30 & 25 & 0 & 20 & 20 \\
\hline Fonias & Fonias Springs & 12.1 & 25.620474 & 40.453815 & 1.8 & 98.2 & 0 & 0 & 30 & 40 & 20 & 0 & 10 & 0 \\
\hline Fonias & Fonias 1 & 12.2 & 25.645155 & 40.478003 & 9.5 & 89.3 & 1.2 & 0 & 5 & 70 & 0 & 10 & 15 & 0 \\
\hline Fonias & Fonias 2 & 12.3 & 25.652187 & 40.489934 & 8.8 & 82.9 & 8.3 & 0 & 70 & 10 & 0 & 5 & 15 & 0 \\
\hline Agkistros & Agkistros 1 & 15.1 & 25.652361 & 40.450152 & 45 & 55 & 0 & 0 & 5 & 60 & 30 & 5 & 0 & 0 \\
\hline Agkistros & Agkistros 2 & 15.2 & 25.667252 & 40.456879 & 45.6 & 43.1 & 11.3 & 0 & 0 & 60 & 30 & 5 & 5 & 0 \\
\hline Lagkadiotis & Lagkadiotis & 17.1 & 25.683949 & 40.438833 & 72.4 & 0 & 25.6 & 0 & 0 & 0 & 80 & 10 & 10 & 0 \\
\hline Giali & Giali 1 & 18.1 & 25.635937 & 40.423535 & 3.9 & 96.1 & 0 & 0 & 20 & 40 & 20 & 0 & 20 & 0 \\
\hline Giali & Giali 2 & 18.2 & 25.647496 & 40.411119 & 24.3 & 75.7 & 0 & 0 & 30 & 40 & 20 & 0 & 0 & 10 \\
\hline Kremasto & Kremasto & 19.1 & 25.624175 & 40.415407 & 0 & 100 & 0 & 75 & 10 & 5 & 0 & 5 & 0 & 5 \\
\hline Vatos & Karagiannakis & 20.1 & 25.581668 & 40.421995 & 20.7 & 79.3 & 0.01 & 0 & 70 & 25 & 5 & 0 & 0 & 0 \\
\hline Vatos & Vatos & 20.2 & 25.595528 & 40.404196 & 7.3 & 91.8 & 0.9 & 0 & 30 & 50 & 10 & 0 & 10 & 0 \\
\hline Lakoma & Kasteli & 21.1 & 25.539632 & 40.432352 & 48.9 & 0 & 51.1 & 0 & 30 & 50 & 15 & 5 & 0 & 0 \\
\hline Lakoma & Lakoma 1 & 21.2 & 25.533429 & 40.427271 & 43.6 & 0 & 56.4 & 0 & 5 & 30 & 45 & 10 & 10 & 0 \\
\hline Lakoma & Lakoma 2 & 21.3 & 25.528661 & 40.423500 & 32 & 0 & 68 & 0 & 5 & 50 & 25 & 10 & 10 & 0 \\
\hline Xiropotamos & Xiropotamos 1 & 22.1 & 25.527042 & 40.446744 & 71 & 2.1 & 26.9 & 0 & 50 & 30 & 15 & 3 & 2 & 0 \\
\hline Xiropotamos & Xiropotamos 2 & 22.2 & 25.511741 & 40.426627 & 64.6 & 1.8 & 33.6 & 0 & 20 & 60 & 0 & 18 & 2 & 0 \\
\hline Polipoudi & Alonia & 23.1 & 25.521237 & 40.465115 & 60.7 & 0 & 39.3 & 0 & 30 & 50 & 10 & 10 & 0 & 0 \\
\hline Polipoudi & Polipoudi DS & 23.2 & 25.502996 & 40.457430 & 45.4 & 0 & 54.6 & 0 & 35 & 55 & 5 & 0 & 5 & 0 \\
\hline
\end{tabular}


Table 4. Cont.

$(\mathbf{b})$

\begin{tabular}{|c|c|c|c|c|c|c|c|c|c|c|c|c|c|c|c|c|c|c|c|c|c|c|}
\hline Code & NS & $\mathrm{Q}$ & WT & $\mathrm{pH}$ & EC & $\mathrm{Ca}$ & $\mathrm{Mg}$ & $\mathrm{Na}$ & $\mathbf{K}$ & $\mathrm{HCO}_{3}$ & $\mathrm{SO}_{4}$ & $\mathrm{Cl}$ & $\mathrm{SiO}_{2}$ & TDI & TH & DO & $\mathrm{N}-\mathrm{NO}_{3}$ & $\mathrm{~N}-\mathrm{NO}_{2}$ & $\mathrm{~N}-\mathrm{NH}_{4}$ & $\mathrm{P}_{-} \mathrm{PO}_{4}$ & TP & Ph Ch Q \\
\hline & & $\mathrm{m}^{3} / \mathrm{s}$ & ${ }^{\circ} \mathrm{C}$ & & $\mu \mathrm{s} / \mathrm{cm}$ & & & & & $\mathrm{mg} / \mathrm{L}$ & & & & & $\mathrm{mg} / \mathrm{L} \mathrm{CaCO} 3$ & & & $\mathrm{mg} / \mathrm{L}$ & & & & \\
\hline 1.1 & 1 & 0.030 & 17 & 7.26 & 188 & 33.77 & 4.7 & 7.63 & 0.41 & 112.7 & 12.58 & 15.3 & 11.3 & 198.4 & 103.59 & & 1.409 & & & & & \\
\hline 1.2 & 3 & 0.042 & 19.7 & 7.93 & 324 & 50.38 & 6.85 & 14.88 & 2.62 & 163.5 & 15.13 & 16.31 & 12.6 & 282.3 & 153.87 & 9.06 & 2.660 & 0.018 & 0.033 & 0.276 & 0.354 & M \\
\hline 1.3 & 1 & 0.032 & 24.8 & 8.05 & 331 & 52.05 & 7.19 & 13.4 & 2.33 & 182.6 & 15.49 & 12.41 & 12.4 & 297.9 & 159.44 & 8.77 & 0.858 & & 0.026 & 0.166 & 0.172 & G \\
\hline 6.1 & 2 & 0.145 & 14.5 & 7.80 & 67 & 14.29 & 3.29 & 6.42 & 0.67 & 59.2 & 7.74 & 6.79 & 11.7 & 110.3 & 49.15 & 10.05 & 0.403 & 0.001 & 0.016 & 0.005 & & $\mathrm{H}$ \\
\hline 7.1 & 2 & 0.051 & 16.7 & 7.86 & 149 & 20.81 & 4.25 & 7.71 & 0.55 & 78.1 & 8.56 & 8.45 & 14.6 & 142.9 & 69.40 & 9.90 & 0.187 & 0.002 & 0.017 & 0.011 & 0.022 & $\mathrm{H}$ \\
\hline 8.1 & 2 & 0.109 & 18.1 & 7.25 & 49 & 16.77 & 4.03 & 8.83 & 0.52 & 67.7 & 7.54 & 9.45 & 13.4 & 128.2 & 58.38 & 9.61 & 0.281 & 0.002 & 0.038 & 0.008 & 0.014 & $\mathrm{H}$ \\
\hline 9.1 & 2 & 0.082 & 16.6 & 7.4 & 53 & 6.9 & 1.2 & 4.7 & 0.8 & 24.4 & 6.7 & 5.1 & 6.8 & 58.2 & & & 0.567 & 0.001 & 0.018 & 0.011 & 0.025 & $\mathrm{H}$ \\
\hline 9.2 & 2 & 0.110 & 16.1 & 7.4 & 46 & 6.4 & 1.1 & 4.9 & 0.8 & 24.4 & 5.9 & 5.7 & 6.3 & 54.3 & 20.4 & 10.32 & 0.545 & 0.001 & 0.020 & 0.015 & 0.039 & $\mathrm{H}$ \\
\hline 9.3 & 9 & 0.072 & 20.2 & 7.4 & 112 & 14.2 & 2.7 & 7.3 & 0.3 & 54.9 & 10.1 & 9.4 & 9.3 & 107.5 & 41.0 & 9.52 & 0.498 & 0.001 & 0.015 & 0.030 & 0.070 & $\mathrm{H}$ \\
\hline 9.4 & 1 & 0.010 & 16.5 & 8.1 & 92 & & & & & & & & & & & 9.79 & 0.064 & $<\mathrm{LOQ}$ & 0.011 & 0.005 & & $\mathrm{H}$ \\
\hline 9.5 & 1 & 0.021 & 19.9 & 6.92 & 109 & 15.47 & 3.19 & 7.35 & 0.72 & 62.8 & 13.52 & 10.54 & 11.5 & 125.2 & 51.72 & 8.85 & 0.244 & 0.001 & 0.022 & 0.013 & & $\mathrm{H}$ \\
\hline 10.1 & 2 & & 17.1 & & 76 & & & 6.65 & 0.71 & & 5.65 & & & & & & & & & 0.009 & 0.020 & $\mathrm{H}$ \\
\hline 11.1 & 1 & 0.083 & 19.8 & 6.41 & 55 & 5.85 & 1.1 & 6.89 & 0.1 & 27.3 & 3.95 & 9.21 & 14.2 & 68.5 & 19.1 & 9.22 & 0.111 & 0.001 & 0.124 & 0.039 & 0.087 & G \\
\hline 11.2 & 1 & 0.061 & 26.1 & 6.81 & 104 & 13.31 & 2.06 & 8.12 & 0.61 & 57.9 & 4.74 & 9.21 & 16.2 & 112.1 & 41.68 & 7.65 & 0.278 & 0.002 & 0.027 & 0.005 & 0.032 & $\mathrm{H}$ \\
\hline 12.1 & 2 & 0.385 & 14.5 & 7.5 & 49 & 6.3 & 1.0 & 5.4 & 0.7 & 24.4 & 4.8 & 5.2 & 6.7 & 56.9 & 19.7 & 10.30 & 0.570 & 0.001 & 0.030 & 0.005 & 0.017 & $\mathrm{H}$ \\
\hline 12.2 & 5 & 0.199 & 13.7 & 7.2 & 159 & 7.1 & 1.3 & 6.5 & 0.8 & 30.5 & 4.8 & 7.1 & 8.1 & 64.9 & & 10.68 & 0.473 & 0.001 & 0.026 & 0.007 & 0.017 & $\mathrm{H}$ \\
\hline 12.3 & 9 & & 14.8 & 7.8 & 68 & & & & & & & & & & & & & & & & & $\mathrm{H}$ \\
\hline 15.1 & 3 & 0.206 & 15.8 & 8.05 & 97 & 16.96 & 2.38 & 8.21 & 0.72 & 48. & 13.03 & 13. & 9.8 & & & & 0.823 & & & & 0.0 & $\mathrm{H}$ \\
\hline 15.2 & 2 & 0.240 & 19.3 & 7.54 & 126 & 16.34 & 2.74 & 9.19 & 0.84 & 54.9 & 13.83 & 11.34 & 11.4 & 120.8 & 52.0 & 10.19 & 0.456 & 0.001 & 0.020 & 0.015 & 0.022 & $\mathrm{H}$ \\
\hline 17.1 & 1 & 0.038 & 22.3 & 7.14 & 252 & 48.67 & 5.27 & 11.09 & 0.07 & 158.0 & 13.96 & 17.11 & 12.88 & 267.1 & & 7.77 & 0.151 & $<\mathrm{LOQ}$ & & 0.005 & 0.005 & $\mathrm{H}$ \\
\hline 18.1 & & & 24.2 & 7.17 & 82 & & & & & & & & & & & & 0.6 & & & & & G \\
\hline 18.2 & 2 & 0.315 & 19.1 & 7.52 & 63 & & & 7. & 1. & 3 & & & & & & & & & & 114 & 0.029 & $\mathrm{H}$ \\
\hline 19.1 & 1 & & 20. & 7.0 & 10 & & & 34 & 1. & & & & 18 & & & 8.1 & 0.720 & & & & 0.088 & G \\
\hline 20.1 & & 0.307 & 21.1 & 6.84 & 106 & & & 11.07 & 1.1 & 46 & & 14 & 17.0 & & & 7. & & 0.0 & 0.0 & 0.023 & 0.035 & $\mathrm{H}$ \\
\hline 20.2 & 2 & 0.364 & 17.6 & 7.6 & 77 & & 2.27 & & 1. & 46 & & & 9.7 & & & 10. & 0.351 & 0.0 & & & 0.026 & $\mathrm{H}$ \\
\hline 21.1 & & 0.040 & 20.4 & 7.33 & 379 & 57.98 & 14.68 & 20.28 & 0.27 & 208.3 & 25. & & 19.5 & & & & & 0.004 & 0.009 & 0.059 & 0.082 & G \\
\hline 21.2 & 3 & 0.785 & 18.7 & 7.80 & 325 & 61.27 & 13.05 & 22.26 & 1.67 & & & & 17.1 & & & & & 0.002 & 0.036 & 0.045 & 0.054 & G \\
\hline 21.3 & 3 & 0.0 & 16 & 7.5 & & & 15. & 30. & 3. & & 28 & 35 & 18 & & & 8. & 2.2 & 0.0 & & & 0.191 & M \\
\hline 22.1 & 4 & 0.1 & 15.1 & 7.97 & 20 & 33.22 & 3.35 & 7.28 & 0.86 & 102.5 & 11.46 & 7.98 & 9.7 & 176.4 & 96.6 & & 0.479 & & & & & $\mathrm{H}$ \\
\hline 22.2 & 1 & 0.045 & 19.1 & 8.3 & 23 & & & & & & & & & & & & 0.143 & $<L O Q$ & 0.008 & & & $\mathrm{H}$ \\
\hline 23.1 & 2 & 0.014 & 16.9 & 8.07 & 313 & 51.4 & 7.30 & 13.39 & 0.77 & 170.19 & 13.2 & 16.51 & 13.2 & 285.7 & 158.29 & 10.04 & 0.848 & 0.001 & 0.036 & 0.024 & & $\mathrm{H}$ \\
\hline 23.2 & 1 & 0.016 & 23.7 & 7.42 & 390 & & 11.01 & 16.83 & 0.30 & 223.26 & & & & 391.9 & & 8.30 & 1.786 & 0.002 & 0.014 & 0.069 & 0.113 & G \\
\hline & & 0.141 & & 7.50 & 158 & 25.14 & & & 0.91 & & & & & & & & & & & & & \\
\hline
\end{tabular}

A: average. The chemical-physicochemical quality has been estimated using the median values of DO, nitrate, nitrite, ammonium, phosphate, and total phosphorous. Colors represent the quality classes according to the Water Framework Directive (WFD) prescriptions: blue $=$ high, green $=$ good, yellow $=$ moderate, orange $=$ poor, and red $=$ bad. 
Table 5. Comparison of water quality parameters among Greek mainland rivers (71 sites), Greek island streams (12 sites), and Samothraki streams (30 sites). TDI includes $\mathrm{SiO}_{2}$. Numbers in parenthesis represent major ion and silicate proportions (calculated from mg/L).

\begin{tabular}{|c|c|c|c|c|c|c|c|c|c|c|c|c|c|c|c|}
\hline & EC & $\mathrm{pH}$ & DO & $\mathrm{Ca}^{2+}$ & $\mathrm{Mg}^{2+}$ & $\mathrm{Na}^{+}$ & $\mathrm{K}^{+}$ & $\mathrm{HCO}_{3}^{-}$ & $\mathrm{CO}_{3}{ }^{2-}$ & $\mathrm{SO}_{4}{ }^{2-}$ & $\mathrm{Cl}^{-}$ & $\mathrm{SiO}_{2}$ & TDI & $\mathrm{TH}$ & $\mathrm{Na}^{+} / \mathrm{Cl}^{-}$ \\
\hline & $\mu \mathrm{S} / \mathrm{cm}$ & & & \multicolumn{9}{|c|}{$\mathrm{mg} / \mathrm{L}$ (\% ions) } & \multicolumn{3}{|c|}{$\mathrm{mg} / \mathrm{L} \mathrm{CaCO}{ }_{3}$} \\
\hline Greek Mainland & 457.7 & 8.03 & 9.82 & $53.3(15.06)$ & $15.3(3.89)$ & $11.3(3.41)$ & $2.7(0.98)$ & $192.4(56.05)$ & $6.3(1.80)$ & $42.8(10.64)$ & $12.3(3.37)$ & $12.0(4.80)$ & 348.3 & 223.9 & 1.3 \\
\hline Greek Islands & 767.1 & 8.61 & 9.80 & 75.1 (12.98) & $36.3(5.93)$ & 35.7 (5.53) & $2.1(0.38)$ & 294.7 (51.82) & $15.2(2.14)$ & $72.6(10.63)$ & $54.2(8.37)$ & $13.4(2.24)$ & 599.4 & 337.3 & 1.0 \\
\hline Samothraki & 148.9 & 7.48 & 9.35 & $23.3(13.04)$ & $4.3(2.39)$ & $12.7(8.13)$ & $0.9(0.63)$ & 81.6 (46.89) & $0.3(0.08)$ & $11.7(7.64)$ & 18.5 (11.53) & $13.2(9.67)$ & 166.4 & 75.7 & 1.15 \\
\hline Mainland/Samothraki & 3.1 & 1.1 & 1.1 & $2.3(1.2)$ & $3.6(1.6)$ & $0.9(0.4)$ & $3.0(1.6)$ & $2.4(1.2)$ & $21.0(22.5)$ & 3.7 (1.4) & $0.7(0.3)$ & $0.9(0.5)$ & 2.1 & 3.0 & \\
\hline Islands/Samothraki & 5.2 & 1.2 & 1.1 & $3.2(1.0)$ & $8.4(2.5)$ & $2.8(0.7)$ & $2.3(0.6)$ & $3.6(1.1)$ & $50.7(26.7)$ & $6.2(1.4)$ & $2.9(0.7)$ & $1.0(0.2)$ & 3.6 & 4.5 & \\
\hline
\end{tabular}


Table 6. Comparison between average nutrient concentrations in Samothraki streams (16 stream, 30 sites) and the Greek average (in parenthesis, the number of samples for individual nutrients).

\begin{tabular}{cccccc}
\hline & $\mathbf{N}-\mathrm{NO}_{3}{ }^{-}$ & $\mathbf{N}-\mathrm{NO}_{2}{ }^{-}$ & $\mathbf{N}-\mathrm{NH}_{4}{ }^{+}$ & $\mathbf{P - P O}_{4}{ }^{3-}$ & Total $\mathbf{P}$ \\
\cline { 2 - 6 } & \multicolumn{5}{c}{$\mathbf{m g} / \mathbf{L}$} \\
\hline Greece & $1.11(754)$ & $0.030(754)$ & $0.18(737)$ & $0.12(749)$ & $0.07(252)$ \\
Samothraki & 0.74 & 0.002 & 0.032 & 0.03 & 0.06 \\
Greece/Samothraki & 1.5 & 15.0 & 5.6 & 4.0 & 1.2 \\
\hline
\end{tabular}

Table 7. Hydrochemical types of springs (SX), streams (XY), and rainfall (RX) (based on meg/L) and their classifications according to TH and TDI (based on $\mathrm{mg} / \mathrm{L}$ ).

\begin{tabular}{|c|c|c|c|}
\hline \multicolumn{2}{|c|}{ Hydrochemical Types } & Hydrochemical Subtypes & Springs, Streams, and Rain Events \\
\hline \multicolumn{2}{|c|}{ Calcium hydrogen carbonate types } & $\begin{array}{l}\mathrm{Ca}^{2+}>\mathrm{Na}^{+}>\mathrm{Mg}^{2+}>\mathrm{K}^{+}-\mathrm{HCO}_{3}{ }^{-}>\mathrm{Cl}^{-}>\mathrm{SO}_{4}{ }^{2-} \\
\mathrm{Ca}^{2+}>\mathrm{Na}^{+}>\mathrm{Mg}^{2+}>\mathrm{K}^{+}-\mathrm{HCO}_{3}{ }^{-}>\mathrm{SO}_{4}{ }^{2-}>\mathrm{Cl}^{-} \\
\mathrm{Ca}^{2+}>\mathrm{Mg}^{2+}>\mathrm{Na}^{+}>\mathrm{K}^{+}-\mathrm{HCO}_{3}{ }^{-}>\mathrm{Cl}^{-}>\mathrm{SO}_{4}{ }^{2-} \\
\mathrm{Ca}^{2+}>\mathrm{Mg}^{2+}>\mathrm{Na}^{+}>\mathrm{K}^{+}-\mathrm{HCO}_{3}{ }^{-}>\mathrm{SO}_{4}{ }^{2-}>\mathrm{Cl}^{-}\end{array}$ & $\begin{array}{c}3 \mathrm{~S}, 4 \mathrm{~S}, 9 \mathrm{~S}, 11 \mathrm{~S}, 14 \mathrm{~S}, 17 \mathrm{~S}, 19 \mathrm{~S}, 1.2,6.1,8.1,9.1, \\
9.2,9.3,9.5,10.1,11.1,11.2,12.1,12.2,12.3, \\
15.1,15.2,17.1,18.1,18.2,20.1,20.2,21.3, \mathrm{R} 1, \\
\mathrm{R} 2 \\
10 \mathrm{~S}, 21 \mathrm{~S}, 22.1 \\
1 \mathrm{~S}, 2 \mathrm{~S}, 5 \mathrm{~S}, 1.1,1.3,7.1,21.1,21.2,23.1 \\
15 \mathrm{~S}, 20 \mathrm{~S}, 23.2\end{array}$ \\
\hline \multirow[t]{2}{*}{ Sodium types } & Sodium chloride & $\mathrm{Na}^{+}>\mathrm{Ca}^{2+}>\mathrm{Mg}^{2+}>\mathrm{K}^{+}-\mathrm{Cl}^{-}>\mathrm{HCO}_{3}{ }^{-}>\mathrm{SO}_{4}{ }^{2-}$ & 16S, 19.1 \\
\hline & $\begin{array}{l}\text { Sodium } \\
\text { sulphate-geothermal }\end{array}$ & $\mathrm{Na}^{+}>\mathrm{Ca}^{2+}>\mathrm{Mg}^{2+}>\mathrm{K}^{+}-\mathrm{SO}_{4}{ }^{2-}>\mathrm{HCO}_{3}{ }^{-}>\mathrm{Cl}^{-}$ & $6 \mathrm{~S}, 7 \mathrm{~S}$ \\
\hline \multicolumn{4}{|c|}{ Water hardness (mg/L)-classification after [7] } \\
\hline \multicolumn{4}{|c|}{ Total dissolved solids (mg/L)-classification after [14] } \\
\hline \multicolumn{2}{|c|}{$\begin{array}{c}<100 \text { (slight mineralization) } \\
\text { 101-225 (low mineralization) } \\
226-350 \text { (medium mineralization) } \\
>350 \text { (high mineralization) }\end{array}$} & \multicolumn{2}{|c|}{$\begin{aligned} \mathrm{S} 1, \mathrm{~S} 2, \mathrm{~S} 3, \mathrm{~S} 5, \mathrm{~S} 11, \mathrm{~S} 15, \mathrm{~S} 19, \mathrm{~S} 21, \mathrm{~S} 24,1.1,6.1,7.1,8.1,9.3,9.5,11.2,15.1,15.2,19.1,20.1,20.2,22.1 \\
\mathrm{~S} 16,1.2,1.3,17.1,23.1\end{aligned}$} \\
\hline
\end{tabular}

Regarding total hardness (TH), the majority of springs and streams (57\%) revealed soft waters, $17 \%$ were medium-hard, $11 \%$ were hard, and $14 \%$ very hard. Regarding TDI, the majority of springs and streams ( $74 \%$ ) revealed slight-to-low mineralization, $9.3 \%$ medium, and $16.7 \%$ high mineralization. Hot springs illustrated extreme mineralization and $\mathrm{TH}$.

Although average nutrient concentrations correspond to reference (nitrite, phosphate, and TP) or nearly reference (ammonium) conditions, average nitrate belongs to a moderate quality status. With the exception of two streams affected by untreated municipal waste waters (Katsambas and Lakoma), $90 \%$ of the nitrite, ammonium, phosphate, and TP measurements fall within high quality status. In contrast, nitrate concentrations vary considerably among sites, ranging from high (only six sites) to bad. Even high-altitude sites ( $>580 \mathrm{~m}$ asl), where human pressures are absent (besides free-grazing goats), revealed relatively high nitrate concentrations resulting to good (Fonias and Platia) or moderate (Giali and Kremasto) nitrate quality (Table 4 b).

\subsubsection{Origin of Stream Water Composition}

Results of Cross Correlations

According to the results of the cross-correlation analysis applied on springs, the EC was primarily correlated with calcium $(r=0.685, p<0.005)$; hydrogen carbonate $(r=0.721, p<0.005)$; and magnesium $(\mathrm{r}=0.759, p<0.005)$. Among major ions, stronger correlations illustrated hydrogen carbonate with calcium $(r=0.971, p<0.001)$ and magnesium $(r=0.723, p<0.005)$ and sodium with chloride $(r=0.779$, 
$p<0.005)$ and magnesium $(\mathrm{r}=0.740, p<0.005)$. Sodium, magnesium, and calcium presented the strongest anticorrelations with altitude $(\mathrm{r}=-0.688, p<0.005 ; \mathrm{r}=0.596, p<0.05$; and $\mathrm{r}=-0.550$, $p<0.05$, respectively). Phosphate correlated with potassium $(\mathrm{r}=0.622, p<0.01)$. Negative correlations between DO and WT $(r=-0.632, p<0.005)$ and between the EC and altitude $(r=-0.577, p<0.05)$ were also apparent.

In streams, the EC presented strong positive correlations with all major ion (except potassium) and silicate concentrations (Ca: $\mathrm{r}=0.845, p<0.001 ; \mathrm{Mg}: \mathrm{r}=0.816, p<0.001 ; \mathrm{Na}: \mathrm{r}=0.689, p<0.001$; $\mathrm{HCO}_{3}: \mathrm{r}=0.816, p<0.001 ; \mathrm{SO}_{4}: \mathrm{r}=0.727, p<0.001 ; \mathrm{Cl}: \mathrm{r}=0.674, p<0.001 ;$ and $\mathrm{SiO}_{2}: \mathrm{r}=0.497$, $p<0.005)$. Major ions and silicate concentrations presented strong positive correlations with each other; predominately, hydrogen carbonate with calcium $(\mathrm{r}=0.966, p<0.001)$ and magnesium $(\mathrm{r}=0.919$, $p<0.001)$; magnesium with sulphate $(\mathrm{r}=0.856, p<0.001)$; and sodium with chloride $(\mathrm{r}=0.902$, $p<0.001)$.

The EC correlated negatively with the mean stream basin altitude $(\mathrm{r}=-0.620, p<0.001)$ and slope $(\mathrm{r}=-0.498, p<0.01)$ and the portion of granites in stream basins $(\mathrm{r}=-0.583, p<0.01)$ and positively with a portion of the Plio-Quaternary sediments $(\mathrm{r}=0.686, p<0.001)$. Like the EC, more or less, all major ions (except potassium) and silicate concentrations were negatively correlated with the mean stream basin altitude (particularly, for sodium and chloride, $\mathrm{r}=-0.624, p<0.001$ and $\mathrm{r}=-0.530$, $p<0.005$, respectively) and slope and showed strong positive correlations with the percentage of sediments in stream basins. All major ions (except potassium) and silicate concentrations were negatively correlated with the granite portion, especially hydrogen carbonate and earth alkali ions $\left(\mathrm{HCO}_{3}: \mathrm{r}=-0.853, p<0.001\right.$; $\mathrm{Ca}: \mathrm{r}=-0.825, p<0.001$; and $\left.\mathrm{Mg}: \mathrm{r}=-0.763, p<0.001\right)$. While major ion concentrations did not show any relationships to WT, the latter was negatively correlated with silicate $(0.547, p<0.005)$. Finally, no correlations between the ophiolitic rock percentage and major ions or silicate concentrations were apparent.

Nutrients correlated with each other, particularly nitrate, nitrite, phosphate, and TP, however weakly $(\mathrm{r}<0.470, p<0.05)$. Relatively weak correlations between TP and TN with the portion of sediments and agricultural areas within stream basins were also apparent $(\mathrm{r}<0.530, p<0.05)$. As with springs, phosphate correlated positively with potassium $(0.400, p<0.05)$. WT was negatively correlated with average stream basin altitude $(\mathrm{r}=-0.398, p<0.05)$ and slope $(\mathrm{r}=-0.495, p<0.01)$ and DO $(\mathrm{r}=-0.779, p<0.001)$. DO and $\mathrm{pH}$ presented a relatively weak positive correlation $(\mathrm{r}=0.416, p<0.05)$.

Considering stream ion proportions, the EC correlated positively only with $\% \mathrm{Ca}$ and $\% \mathrm{HCO}_{3}$ $(\mathrm{r}=0.716$ and $\mathrm{r}=0.693$, respectively; $p<0.001)$ and presented negative correlations predominately with $\% \mathrm{SiO}_{2}(-0.766, p<0.001)$ and $\% \mathrm{Na}(-0.683, p<0.001)$. Negative correlations among ions and silicate proportions prevailed. For example, $\%$ Ca correlated positively only with $\% \mathrm{HCO}_{3}(\mathrm{r}=0.838$, $p<0.001)$ and negatively predominately with $\% \mathrm{Na}(\mathrm{r}=0.930, p<0.001)$ and $\% \mathrm{Cl}(\mathrm{r}=0.772, p<0.001)$. Only $\% \mathrm{Ca}$ and $\% \mathrm{HCO}_{3}$ were negatively correlated with the average basin altitude. The proportions of all other major ions were positively correlated with the average basin altitude (especially, $\% \mathrm{SO}_{4}$ : $\mathrm{r}=0.710, p<0.001 ; \% \mathrm{Na}: \mathrm{r}=0.575, p<0.005 ;$ and $\% \mathrm{~K}: \mathrm{r}=0.507, p<0.005)$. As with concentrations, the $\% \mathrm{Ca}, \% \mathrm{Mg}$, and $\% \mathrm{HCO}_{3}$ were negatively correlated with the portion of granites in stream basins. However, the proportions of sodium, chloride, silicate, and sulphate were positively correlated with the granite portion $(\mathrm{r}=0.886, p<0.001 ; 0.834, p<0.001 ; 0.716, p<0.001$; and $\mathrm{r}=0.540, p<0.005$, respectively). Additionally, unlike with concentrations, the proportions of sodium, chloride, silicate, and sulphate were negatively correlated with the sediment portion in stream basins $(\mathrm{r}=-0.656$, $r=-0.686, r=-0.667$, and $r=-0.640$, respectively; $p<0.001$ ). Finally, the majority of ion proportions revealed clear relationships to the ophiolites portion (e.g., \%Ca: $\mathrm{r}=0.641, p<0.001 ; \% \mathrm{HCO}_{3}: \mathrm{r}=0.515$, $p<0.01$; \% Na: $\mathrm{r}=-0.715, p<0.001$; and $\% \mathrm{Cl}: \mathrm{r}=-0.642, p<0.001)$.

\section{Results of Cluster Analysis}

From the cluster analysis (Table 8), the following results may be obtained: (i) the examined waters belong to three main groups; while two springs ( $4 \mathrm{~S}$ and 20S) presented significant differentiations from 
these groups, (ii) streams and springs presented hydrochemical similarities. Evident from several highly correlated subgroups that include both stream sites and springs, (iii) a number of streams and springs (primarily from group 1 and secondarily from group 2) presented high similarities to rain water, and (iv) there were minor relationships between the composition of streams and springs and the prevailing magmatic rock types in the respective basins. This derives from the fact that several highly correlated waters were related to differing magmatic rock types (i.e., almost monolithic granite and ophiolite basins) (Tables 8 and $4 \mathrm{a}$ ), and (v) stream sites of the same basin may belong to different hydrochemical groups.

Table 8. Summarized results of cluster and Simper analysis.

\begin{tabular}{|c|c|c|c|c|}
\hline & & \multicolumn{3}{|c|}{ Similarities within Groups (Euclidean Distance) and Group Characteristics } \\
\hline & & Group 1 & Group 2 & Group 3 \\
\hline & & $\begin{array}{c}\mathrm{R} 1, \mathrm{R} 2,9 \mathrm{~S}, 10 \mathrm{~S}, 14 \mathrm{~S}, 9.1,9.2 \\
12.1,12.2,12.3\end{array}$ & $\begin{array}{c}11 S, 12 S, 13 S, 17 S, 19 S, 21 S \\
22 S, 23 S, 24 S, 6.1,7.1,8.1,9.3 \\
9.5,10.1,11.1,11.2,15.1,15.2 \\
18.1,18.2,20.1,20.2\end{array}$ & $\begin{array}{c}1 \mathrm{~S}, 2 \mathrm{~S}, 3 \mathrm{~S}, 5 \mathrm{~S}, 15 \mathrm{~S}, 16 \mathrm{~S}, 18 \mathrm{~S}, 1.1 \\
1.2,1.3,17.1,19.1,21.1,21.2, \\
21.3,22.1,23.1,23.2[\mathrm{~s} 1]\end{array}$ \\
\hline & & 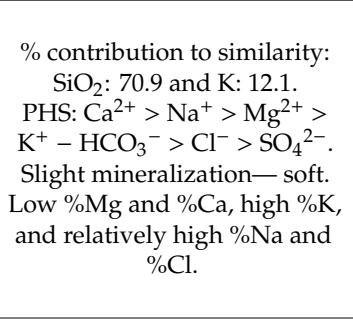 & 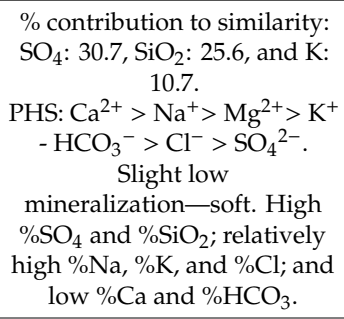 & $\begin{array}{c}\text { \% contribution to similarity: } \\
\mathrm{SiO}_{2} \text { : } 31.6, \mathrm{Mg}: 13.8, \mathrm{HCO}_{3} \text { : } \\
\text { 13.0, and } \mathrm{Ca}: 11.9 . \\
\mathrm{PHS}: \mathrm{Ca}^{2+}>\mathrm{Mg}^{2+}>\mathrm{Na}^{+}> \\
\mathrm{K}^{+}-\mathrm{HCO}_{3}{ }^{-}>\mathrm{Cl}^{-}>\mathrm{SO}_{4}{ }^{2-} \\
\quad \text { Medium-high } \\
\text { mineralization-soft to very } \\
\text { hard. Very high }[\mathrm{Ca}] \text { and } \\
{[\mathrm{HCO}] \text {; high }[\mathrm{Mg}],[\mathrm{Na}], \text { and }} \\
{[\mathrm{Cl}] ; \text { and low } \% \mathrm{~K} \text { and } \% \mathrm{SiO}_{2} \text {. }}\end{array}$ \\
\hline \multirow[t]{2}{*}{$\begin{array}{l}\text { Differences among } \\
\text { groups (Euclidean } \\
\text { distance) }\end{array}$} & Group 1 & & $\begin{array}{c}\text { \% contribution to } \\
\text { differentiation: } \\
\mathrm{SiO}_{2} \text { v: } 59.7 \text { and } \mathrm{SO}_{4} \text { v: } 17.2 \text {. }\end{array}$ & $\begin{array}{c}\text { \% contribution to } \\
\text { differentiation: } \\
\mathrm{SiO}_{2} \text { v: } 25.2, \mathrm{Ca} \text { v: } 19.3, \mathrm{HCO}_{3} \\
\text { v: } 18.2, \text { and } \mathrm{Mg} \mathrm{v}: 13.6 .\end{array}$ \\
\hline & Group 2 & & & $\begin{array}{c}\text { \% contribution to } \\
\text { differentiation: } \\
\text { Ca v: } 22.2, \mathrm{HCO}_{3} \text { v: } 21.3, \mathrm{SO}_{4} \\
\text { v: } 16.8, \text { and } \mathrm{Mg}: \mathrm{v} 15.2 .\end{array}$ \\
\hline
\end{tabular}

Colors represent prevailing rock type in stream basin area or spring aquifer: red for granites, green for ophiolites, red and green if ophiolites and granites are equally represented, and blue = basement unit (metamorphosed sedimentary rocks). Comments refer to streams. If sedimentary rocks dominate in stream basin areas or spring aquifers, a granitic or ophiolithic composition has been selected according to the prevailing parent rock type. PHS: predominant hydrochemical subtype, [...]: concentration, and v: horizontal groups contain lower concentrations than vertical groups.

Group 1 consists of the rain events and eight spring and stream sites, with slightly mineralized (average TDI: $62.2 \mathrm{mg} / \mathrm{L}$ ) soft waters. Rain water solute concentrations were comparable to springs and streams. Spring and stream sites belong to two basins (Fonias and Platia) with distinct geology (mainly granites and mainly ophiolites, respectively). According to a Simper analysis, waters in this group were characterized by a high similarity regarding silicate. Besides low concentrations of major ions and silicate, this group is also characterized by low magnesium and calcium proportions, high potassium, and relatively high sodium and chloride proportions. Finally, group 1 waters belong to the calcium hydrogen carbonate subtype: $\mathrm{Ca}^{2+}>\mathrm{Na}^{+}>\mathrm{Mg}^{2+}>\mathrm{K}^{+}-\mathrm{HCO}_{3}{ }^{-}>\mathrm{Cl}^{-}>\mathrm{SO}_{4}{ }^{2-}$, with the exception of 10S (Table 7).

Group 2 refers to 23 spring and streams sites with soft waters (with two exceptions showing medium hardness), ranging between slight to low mineralization. It is related to group 1 but presents a higher mean TDI (101.8 mg/L). Waters of this group illustrate high similarities regarding sulphate, silicate, and potassium (Table 8). Streams are scattered throughout the central and eastern parts of the island and belong to nine river basins with variable geological backgrounds (Figure 1 and Table 4a). The majority of springs belong to the central and southern part of the island. Streams belong to the same calcium hydrogen carbonate subtype as in group 1, besides 7.1 (Table 7). A number of 
springs belong to the aforementioned calcium hydrogen carbonate subtype, while others fit in the two sodium-hydrogen-carbonate subtypes (Table 7).

Group 3 is composed by 7 springs and 11 stream sites, predominately located at the western part of the island. Here belong also the polluted streams Katsambas and Lakoma. A number of sites (i.e., 15S, 16S, 18S, 17.1, and 19.1) are scattered on the central and eastern parts of the island. Group 3 reveals a medium mineralization (TDI: $298.2 \mathrm{mg} / \mathrm{L}$ on the average) and generally hard waters with very high calcium, magnesium, and hydrogen carbonate concentrations and low potassium and silicate proportions. The similarity of the waters in this group is attributed to silicate, magnesium, hydrogen carbonate, and calcium. The predominant hydrochemical subtype is: $\mathrm{Ca}^{2+}>\mathrm{Mg}^{2+}>\mathrm{Na}^{+}>\mathrm{K}^{+}-$ $\mathrm{HCO}_{3}{ }^{-}>\mathrm{Cl}^{-}>\mathrm{SO}_{4}{ }^{2-}$ (Table 8). A spring (16S) and a stream site (19.1) located at the south-eastern part of the island, build a subgroup within group 3, although their watersheds do not show any geological similarities (Figure 1 and Tables $3 a$ and $4 a$ ). They belong to a unique sodium chloride hydrochemical subtype (Table 7) with very high sodium and chloride concentrations and portions and low calcium and hydrogen carbonate portions.

Groups 1 and 2 contain waters with high similarities, particularly in respect to silicate and sulphate, while their main difference is due to the higher sulphate and silicate levels of group 2. Group 1 differs from group 3 in holding waters with lower concentrations of silicate, calcium, hydrogen carbonate, and magnesium. Finally, compared to group 3, group 2 waters show lower concentrations in calcium, hydrogen carbonate, sulphate, and magnesium (Table 8).

Three springs: 4S, 18S, and 20S revealed high dissimilarities from the three groups discussed above. Spring $18 \mathrm{~S}$ (not include in the cluster analysis due to its high dissimilarity), located within granites at the southern part of the island, belongs to a rare sodium hydrogen carbonate type. It presents slight mineralization and soft waters (Table 7) and a unique composition in containing the highest silicate concentration measured on the island $(40.9 \mathrm{mg} / \mathrm{L})$. It is additionally characterized by very low earth alkali and hydrogen carbonate and high sodium and chloride concentrations and proportions. Spring $4 \mathrm{~S}$ presents maximum sodium and chloride concentrations and proportions. Its discrimination is attributed to seawater intrusion in the groundwater aquifer. As far as $20 \mathrm{~S}$ is concerned, this spring lies within quaternary sediments and presents the most unique composition of the highest TDI measured on the island $(684.7 \mathrm{mg} / \mathrm{L})$, with the maximum calcium, magnesium, hydrogen carbonate, and sulphate content and minimum potassium content (lower than in rainwater).

\section{Discussion}

\subsection{Hydromorphology}

Samothraki streams are falling abruptly into the sea, as the particularly high stream relief ratios indicate (average 0.20). To compare, the relief ratio of Acheron River in western Greece (where, likewise, Saos Mt. elevation peaks at $1600 \mathrm{~m}$ asl) is only 0.03 [59], and the average relief ratio of 29 mountainous streams in northern Peloponnese lies by 0.09 [60].

Elongated stream basins radiating out of the central heights of the island with parallel drainage pattern and low number of tributaries (and thus, low stream order and drainage density) result from predominant steep relief and weathering resistant rocks [61]. Upstream granitic plateaus of Fonias, Giali, and Agkistros illustrate dendritic drainage networks with higher drainage densities and stream orders due to relatively smooth relief, low structural factor controls, and thus, homogenous erosional resistance, in combination with low permeability of massive granites [62].

Hard lithology, combined with still-ongoing uplift movements, mountainous relief, and high slopes, resulted in the creation of bedrock streams showing that the long-term capacity of the streams to transport bedload exceeds the long-term supply of bedloads [56]. Uplift movements in combination with differing erosional resistance, steep slopes, and high runoffs have created impressive multistep waterfalls and cataracts. 
The vast majority of stream outflows turn westwards before entering the sea as a result of a predominating North-East wind and wave direction. However, subsequent high winter and spring stream flows may straighten river outflows and disconnect the previously westwards-moving branches through the development of barriers composed by bedrock material. This is the mechanism for the development of permanent or temporary (depending on freshwater supply) coastal wetlands (Christos Anagnostou, personal communication).

Low storage capacity of fractured groundwater aquifers, combined with high stream gradients, result in high stream energy and flashy hydrographs [61,63]. The high specific discharge of the Fonias (and obviously, of the other mountainous, magmatic basins too, as the estimated mean specific discharge of the island indicates) is because it is fed by these shallow, fractured groundwater aquifers forcing water from rainfall and snow melt to flow predominately overland. Thus, even during the dry season, when groundwater aquifers are nearly exhausted, rainfalls may cause abrupt disastrous floods, particularly in the Fonias, Agkistros, Giali, and Vatos basins, triggered by the short travel times of water. It is thus not surprising that the name "Fonias" means "killer". After rain events, discharge declines sharply to pre-rain levels. Moreover, with dry conditions prevailing in early summer, groundwater reservoirs are rapidly exhausted, and stream discharge diminishes dramatically, as the substantial drop of the island's runoff from May to June indicates. On the contrary, in sedimentary stream basins located at the western part of the island that are composed by large alluvial aquifers, downwelling processes dominate, as in the case of the Xiropotamos (that means "dry river"), which desiccates in summer at its downstream portion and revealed relatively low specific discharge.

For an island placed in the Aegean Sea, Samothraki is gifted with high annual surface runoff and numerous perennial streams. This is due to the mountainous heights of the island that, contrary to the other Aegean islands, are commonly covered by snow during winter and spring, receive more rainfall, and have lower temperatures and, thus, lower evapotranspiration rates [64]. However, summer rainfalls are rare, as the data of the mountainous meteorological station confirmed. Despite that, numerous small perennial headwater springs surrounding the mountain peaks are outflowing from fractured-type aquifers. These springs feed the streams radiating outwards from the central heights and are considered as the main sources of the island's surface runoff. However, considering the low capacity of fractured ground water aquifers, sparse summer rains alone cannot explain the existence of spring flow during the dry period of the year. We thus assume that spring runoff during summer may be triggered by cloud and fog condensation, which is considered as a significant hydrological input in mountainous areas, or local orographic drizzles [65-67]. These meteorological processes are further corroborated by the common presence of cloud and fog cover over high altitudes, which create water droplets during summer nights, as ground-proofing and the high air humidity frequency observed at the mountainous meteorological station confirmed. High air humidity is explained by the transport of sea vapor toward the island's heights blown by winds that then condensate due to sharp air temperature drops. In addition, the low stream water travel time does not justify increased evapotranspiration. Increased night runoff of the Fonias stream further supports this view, since vapor condensation and orographic drizzles primarily occur during the night when the temperature drops [66] and our meteorological data demonstrated a clear night increase in air humidity. This evidence confirms that vapor condensation and/or orographic drizzles are quantitative and may largely contribute to the existence of perennial springs and streams on the island. Further research is underway to quantify this phenomenon.

\subsection{Hydrogeochemistry}

The vast majority of springs and streams presented excellent qualitative characteristics and may be used for domestic water supplies and bottling suitable for special diets (e.g., a sodium-restricted diet and diet preventing calcium nephrolithiasis) [57]. On the contrary, hot springs practiced for curative drinking should be used carefully due to their high manganese contents. The variety of hydrochemical types and subtypes found on the island indicates that the hydrochemical composition of springs and 
streams varies considerably in the space. It seems likely that hydrochemical variability is triggered by the low solute concentrations, enabling slight spatial environmental variations to be mirrored in the hydrochemical characters of running waters.

The remarkably low solute concentrations of Samothraki streams and springs is attributed to a combination of geological, morphological, and hydro(geo)logical factors. Low solute concentrations result from low-reactive bedrock due to steep gradients and low travel time and, thus, limited interaction between water and bedrock (e.g., [11]). Particularly, streams draining granitic terrains present minimum solute concentrations (as depicted by the inverse relationship between the EC with the granite percentage in stream basins) as a result of their low weatherability. Moreover, the fractured groundwater aquifers developed in magmatic rocks are small and shallow and are composed by coarse material (mainly sand and gravel). These conditions are expected to initiate low residence times and poor solute concentrations in subsurface flow. As the vast majority of the springs belong to this kind of aquifer, spring water is poor in solutes, resembles hydrochemically to stream water (Table 8), and presents, contrary to typical ground water, high DO concentrations (Table 3b).

On the contrary, streams draining sedimentary basins were more enriched in solutes, as the high positive correlation between the portion of sediments in stream basins and the EC indicates, while a downstream mineralization rise (depicted from the anticorrelation between the EC and altitude), together with an increase in sediments, is also apparent. This is because unconsolidated sediments present a higher weathering and dissolution capacity than parent rocks, and as sediments are concentrated in the lowlands, the residence times of surface and subsurface flow should increase. In addition, a downstream rise in evapotranspiration rates and a probable increase of sedimentary groundwater aquifer inputs (that are rich in solutes) to surface runoff may further enhance dissolved solid concentrations $[9,17,63]$. Similar results have been observed in other mountainous magmatic basins too (e.g., [11,68]).

Within streams, the $\mathrm{DO}$ and $\mathrm{pH}$ revealed a relatively weak positive correlation, indicating that biological processes (i.e., photosynthesis and respiration) affect dissolved oxygen and $\mathrm{pH}$ variance by about $20 \%$. Organic matter assimilation processes alone may not explain the drop of DO with diminishing altitude in Samothraki streams, since municipal waste waters affect only two streams, and organic pollution related to leaflitter decomposition in interfering pools and/or small ruminant excrements are distributed independently from altitude [37]. Besides biological processes, DO solubility relates to physical factors, i.e., WT, atmospheric pressure, and turbulence. With increasing altitude, WT drops (by $\sim 1.38^{\circ} \mathrm{C}$ per $100 \mathrm{~m}$ of elevation increase), together with atmospheric pressure $(\mathrm{r}=-0.98$, $p<0.01$; depicted from a cross-correlation analysis on the May 2014 data, which includes atmospheric pressure). A decrease in WT causes a rise in DO solubility, whereas a decrease in atmospheric pressure causes a drop in DO solubility. The net effect of WT and atmospheric pressure results in an overall increase in DO solubility with altitude; for an average WT decrease between headwater and lowland sites of $5.6{ }^{\circ} \mathrm{C}$, DO saturation at the streams' headwaters rises by $1.14 \mathrm{mg} / \mathrm{L}$ (according to Merck [69]), whereas the respective atmospheric pressure diminishing of $72 \mathrm{mb}$ results in a DO drop of $0.63 \mathrm{mg} / \mathrm{L}$ in the headwaters (calculated from https://water.usgs.gov/software/ DOTABLES/ using an average WT of $15^{\circ} \mathrm{C}$ ). Thus, the net effect of water temperature and atmospheric pressure causes a theoretical overall DO increase at the headwaters by $0.51 \mathrm{mg} / \mathrm{L}$. Since DO differences between highland and lowland sites are even smaller, WT rise alone may explain the downstream DO diminishing. The prevalence of WT in controlling DO in Samothraki streams is further corroborated by the strong negative correlation between WT and DO. Finally, as the positive correlation between DO and stream basin slope indicates, high slopes enhance turbidity that acts as a DO enhancement agent in steep mountainous streams.

Although geological controls play a major role in shaping the hydrochemical regime of running waters, in a global, regional, or river basin scale $[7,9,10,14,17,63,70-75]$, this is not particularly apparent for Samothraki streams, where stream hydrochemistry (in terms of ion concentrations) was not particularly dependent on the geology of stream basins (Table 8). As the cluster analysis indicated, even almost monolithic granitic and ophiolitic basins revealed hydrochemical similarities, contrary to 
Meybeck's [70] findings. Additionally, contrary to the findings of other studies $[14,73,76]$ and despite the fact that ophiolite weatherability is eight times higher than that of the granite [77], basins with prevailing ophiolitic bedrock were not characterized by any enrichment in magnesium or silicate, as the cross-correlations illustrated. Actually, the only relationships existing between stream hydrochemistry and granites or ophiolites concern ion proportions. For example, correlation trends of ion proportions point out towards a selective enrichment of sodium, chloride, silicate sulphate, and potassium (in decreasing order) in high altitude granite basins, thus "unmasking" the influence of both granite weathering and/or precipitation inputs. Even the compositions of the springs (which typically show higher residence times and, thus, higher dependency from rock types) were not related to aquifer petrology (Table 8). Thus, the ultimate geological control, shaping major ion and silicate concentrations in stream water, is the abundance of Pliocene and Quaternary sediments in the lowland parts of stream basins. Especially when these sediments were composed by ophiolitic debris (i.e., 1.2, 1.3, 21.2, 21.3, 23.1, and 23.2), in-stream magnesium and silicate concentrations were maximum (Table $4 \mathrm{~b}$ ) as a result of mafic mineral weathering; in these streams, the average molar ratio between $\mathrm{SiO}_{2}$ and $\mathrm{Mg}$ was 0.64 (the rest of Samothraki streams presented $\mathrm{a} \mathrm{SiO}_{2} / \mathrm{Mg}$ ratio of 2.2), i.e., close to the ratios resulting from serpentine or pyroxene weathering ( 0.67 and 0.5 , respectively), while average $\mathrm{pH}(7.8)$ was higher than the average $\mathrm{pH}$ of all other streams (7.4), pointing out mafic mineral weathering reactions consuming $\mathrm{H}^{+}$. Hence, mafic mineral weathering reactions predominately occur in streams draining ophiolitic debris and are negligible in streams draining ophiolitic bedrock. Finally, hydrogen carbonate in streams and springs predominately correlated with calcium, indicating that a dominant geochemical process is calcite dissolution. The importance of carbonate mineral weathering is notable given the fact that carbonate rocks are almost absent, and carbonate minerals may be predominately present in pores of sedimentary rocks or in fresh bedrock, exposed by physical weathering, containing interstitial calcite [78], as similar studies indicated [11,79].

Besides geochemical processes, atmospheric depositions affect stream water composition, especially in pristine basins with limited chemical weathering [80]. The hydrochemical affinity of stream, and even spring, waters to rainfall in a number of basins (Table 8, group 1) points towards the importance of atmospheric sources in shaping the hydrochemical regime of certain Samothraki waters, particularly bedrock streams and springs related to fast-flowing water with slight mineralization. The molar ratios of major ions to chloride (e.g., [81]) present a substantial increase while going from seawater to rainwater, especially for calcium and hydrogen carbonate (two to three orders of magnitude, respectively), indicating increased dust-loading of rain water, particularly with calcite particles. In fact, the molar ratio between $\mathrm{HCO}_{3}$ and $\mathrm{Ca}$ in rainwater equals the respective ratio resulting from calcite dissolution, i.e., two. Focusing on sodium, a Na${ }^{+}$and $\mathrm{Cl}^{-}$correlation $(\mathrm{r}=0.983 p<0.01)$ reveals a slope (1.21) close to the sea salt ratio (1.16) and an intercept close to zero (0.05), supporting their atmospheric origin [82]. However, the mean molar ratio between $\mathrm{Na}^{+}$and $\mathrm{Cl}^{-}$in stream water (1.54) exceeds the seawater ratio (0.86) and the average rainwater ratio (1.0). This may be due to a separation of $\mathrm{Na}^{+}$and $\mathrm{Cl}^{-}$during transport from sea to land, which can lead to an increased sea salt $\mathrm{Na}^{+} / \mathrm{Cl}^{-}$ratio, reaching 1.1-1.8 in continental rain [83]. Geochemical reactions also support the marine origin of sodium in stream water; the mean molar $\mathrm{SiO}_{2}$ to $\mathrm{Na}^{+}$ratio in stream water $(0.53)$ is four times lower than the ratio derived from albite weathering to kaolinite (2.0), indicating that overall only about $25 \%$ of sodium found in streams may be attributed to rock weathering. Finally, the negative correlations of sodium and chloride concentrations with altitude point to the influence of marine aerosol on the lowland stream sites of the island.

The low concentrations of nitrite, ammonia, phosphate, and TP in Samothraki streams are consistent to the minimally disturbed environmental conditions of the island. In contrast, nitrate reveals exceptionally high levels, even in remote mountainous stream reaches. In absence of any fertilizer use in the highlands, these high nitrate concentrations cannot be interpreted, either by the impact of small ruminant excrements or by mineralization of leaflitter in interfering stream pools, since phosphorous, ammonia, and nitrite retain very low concentrations. The most probable 
explanation of the high in-stream nitrate concentrations in mountainous stream reaches is atmospheric deposition. Rain events on Samothraki showed a substantial nutrient enrichment compared to stream water (Tables $3 b$ and $4 b$ ), ranging from 1.5 times (for nitrite) to 11 times (for ammonium) for streams not affected by pollution (Katsambas and Lakoma were excluded, as they receive untreated waste waters). Similar results have been found also in other studies in Greece [14,17]. The reason of such high nutrient levels in rainfall is that atmospheric chemistry in the area is influenced by air masses from anthropogenic sources of Central and Eastern Europe [84]. However, nitrate revealed a lower concentration in rainwater than in mountainous stream reaches. Nevertheless, the fact that only one rainfall event was analyzed for nutrients does not allow us to draw any safe conclusions. Another possible source of nitrate is cloud deposition, i.e., vapor condensation. Cloud water is enriched in pollutants compared to rainwater [85,86]. According to Budhavant et al. [87], who studied atmospheric deposition on a mountainous area, cloud water was more enriched in nitrate than in ammonia, compared to rainwater. Since vapor condensation is assumed to contribute to surface runoff in Samothraki, this mechanism may explain the high nitrate concentrations found in mountainous stream reaches. Additional research focusing on rain and vapor collection, as well as stable N-isotope analyses, are needed to explain the origin of nitrate in Samothraki streams.

\section{Conclusions}

Contrary to other Aegean islands, Samothraki is characterized by exceptionally high surface runoff, with abundant springs and perennial streams. Besides elevated rainfall and snow cover triggered by the mountainous character of the island, field observations and related data indicate that cloud and fog vapor condensation or local orographic drizzles may additionally contribute to surface runoff, especially during the dry period of the year, when rainfalls are scarce.

Tectonic, lithological, and morphological factors resulted in the creation of high-gradient streams, among which, bedrock streams prevail. Multistep waterfalls and interfering pools; restricted and shallow, fractured ground water aquifer; high specific discharge; low stream water travel time; and flashy regimes shape the hydrological characteristics of the main part of the island. In stream basins where sedimentary formations prevail, particularly at the west part of the island, downwelling processes may occur, causing stream desiccation in downstream reaches and a lowering of specific discharges. A combination of morphological, geological, hydro(geo)logical, and atmospheric factors drives a variety of hydrochemical regimes, however common for springs and streams, with markedly low solute concentrations, especially those draining parent magmatic rocks. The vast majority of springs (and even streams) present excellent drinking water quality and taste and may be used as bottled water appropriate for special diets. In contrast, hot springs may not be desirable for curative drinking.

Due to fast-flowing waters, differing geochemical compositions of underlying magmatic rocks (granites vs. ophiolites) do not imprint ionic concentrations. The latter are driven by increased portions of stream basin sediments located at the lowlands, especially when composed by ophiolitic debris. To detect the influence of rock weathering on the hydrochemical composition of springs and streams draining basins with similar physicogeographic conditions as in Samothraki (magmatic basement, bedrock type streams, and high slopes), it is recommended, complementary to ion concentrations, to use ion proportions and/or ionic ratios. In fact, through the application of ion proportions, the geochemical fingertips of granite and ophiolite stream basins have been detected.

In fast-flowing bedrock streams, where weathering rates are negligible, atmospheric deposition may largely control water composition, while atmospheric nutrient inputs seem to be immense. An increase of stream DO with altitude was mainly attributed to physical factors, while nutrient levels were consistent to the nearly pristine environmental conditions of the island. An exception is nitrate, with relatively high concentrations even in headwater streams. This is attributed to rain and snow inputs, and possibly to fog condensation, but these assumptions need further scientific proof. 
Several mountain peaks of the island extend above $1000 \mathrm{~m}$ asl, with a corresponding area of $23 \mathrm{~km}^{2}$. This largely undisturbed landscape, situated within the core area of the NATURA 2000 framework and the proposed Samothraki Island UNESCO-MAB reserve, is the source area of numerous perennial springs with restricted, shallow aquifers. These springs are the sources of major streams, such as Fonias, Agkistros, Xiropotamos, Vatos, and Giali. The hydrological balance of springs and stream headwaters depends on the microclimatic conditions of the mountainous area and is vulnerable even to minor changes. The affinity of Samothraki running water composition to rain water highlights their sensitivity to climatic and atmospheric variability. Thus, any intense human interference within the NATURA 2000 core area that may change microclimatic and hydrological conditions is expected to adversely impact the hydrological and hydrochemical regime of major Samothraki streams and affect the future sustainability and prosperity of the island.

Supplementary Materials: Figure S1 is available online at http://www.mdpi.com/2073-4441/12/2/473/s1.

Author Contributions: N.T.S. designed and performed research, field survey, and writing; A.L. performed research, field survey, statistics, and GIS; and S.L. performed chemical analysis and editing. All authors have read and agreed to the published version of the manuscript.

Funding: Part of this research was funded by the European projects AQEM (ENVK1-1999-00132) and STAR (ENVK1-CT-2001-00089) and the National Monitoring Program (2012-2015).

Acknowledgments: Part of the data were collected in the framework of a master thesis of Anastasia Lampou [38]. My special thanks to Rafaella Balestrini (CNR-IRSA) for productive discussions in the field of major ion and nutrients' atmospheric depositions. Finally, we would like to thank two anonymous reviewers who contributed to the substantial improvement of the manuscript.

Conflicts of Interest: The authors declare no conflict of interest.

\section{References}

1. Meybeck, M. Chemical Characteristics of Rivers. In Fresh Surface Water, Encyclopedia of Life Support Systems (EOLSS); UNESCO: Paris, France, 2009; Volume 1, p. 448.

2. Bøhn, T.; Amundsen, P.-A. Ecological Interactions and Evolution: Forgotten Parts of Biodiversity? Bioscience 2004, 54, 804. [CrossRef]

3. European Environment Agency (EEA). European Waters, Assessment of Status and Pressures; EEA Report; Publications Office of the European Union: Luxembourg, 2018; p. 85. [CrossRef]

4. Petts, G.E. Historical Change of Large Alluvial Rivers: Western Europe; Petts, G.E., Möller, H., Roux, A.L., Eds.; Wiley: Chichester, UK, 1989; p. 355.

5. Feio, M.J.; Aguiar, F.C.; Almeida, S.F.P.; Ferreira, J.; Ferreira, M.T.; Elias, C.; Serra, S.R.Q.; Buffagni, A.; Cambra, J.; Chauvin, C.; et al. Least Disturbed Condition for European Mediterranean rivers. Sci. Total Environ. 2014, 745-756. [CrossRef] [PubMed]

6. Hering, D.; Borja, Á.; Carstensen, J.; Carvalho, L.; Elliott, M.; Feld, C.K.; Heiskanen, A.-S.; Johnson, R.K.; Moe, J.; Pont, D.; et al. The European Water Framework Directive at the age of 10: A critical review of the achievements with recommendations for the future. Sci. Total. Environ. 2010, 408, 4007-4019. [CrossRef] [PubMed]

7. Hem, J.D. Study and interpretation of the chemical characteristics of natural water. In Study and Interpretation of the Chemical Characteristics of Natural Water; US Geological Survey: Reston, VA, USA, 1985; p. 363.

8. Drever, J.I.; Zobrist, J. Chemical weathering of silicate rocks as a function of elevation in the southern Swiss Alps. Geochim. Cosmochim. Acta 1992, 56, 3209-3216. [CrossRef]

9. Skoulikidis, N.T. Significance evaluation of factors controlling river water composition. Environ. Earth Sci. 1993, 22, 178-185. [CrossRef]

10. Bluth, G.J.; Kump, L.R. Lithologic and climatologic controls of river chemistry. Geochim. Cosmochim. Acta 1994, 58, 2341-2359. [CrossRef]

11. Clow, D.W.; Sueker, J.K. Relations between basin characteristics and stream water chemistry in alpine/subalpine basins in Rocky Mountain National Park, Colorado. Water Resour. Res. 2000, 36, 49-61. [CrossRef] 
12. Bouchard, M.; Jolicoeur, S. Chemical weathering studies in relation to geomorphological research in southeastern Canada. Geomorphology 2000, 32, 213-238. [CrossRef]

13. Soulsby, C.; Gibbins, C.; Wade, A.; Smart, R.; Helliwell, R. Water quality in the Scottish uplands: A hydrological perspective on catchment hydrochemistry. Sci. Total. Environ. 2002, 294, 73-94. [CrossRef]

14. Skoulikidis, N.T.; Bertahas, I.; Koussouris, T. The environmental state of freshwater resources in Greece (rivers and lakes). Environ. Earth Sci. 1998, 36, 1-17. [CrossRef]

15. Skoulikidis, N.; Amaxidis, Y.; Bertahas, I.; Laschou, S.; Gritzalis, K. Analysis of factors driving stream water composition and synthesis of management tools-A case study on small/medium Greek catchments. Sci. Total. Environ. 2006, 362, 205-241. [CrossRef] [PubMed]

16. Skoulikidis, N.T. The environmental state of rivers in the Balkans-A review within the DPSIR framework. Sci. Total. Environ. 2009, 407, 2501-2516. [CrossRef] [PubMed]

17. Skoulikidis, N. The State and Origin of River Water Composition in Greece. In The Rivers of Greece; Skoulikidis, N., Dimitriou, E., Karaouzas, I., Eds.; Springer: Berlin, Germany, 2018; pp. 97-128.

18. Skoulikidis, N.; Lampou, A.; Karaouzas, I.; Gritzalis, K.; Lazaridou, M.; Zogaris, S. Stream ecological assessment on an Aegean island: Insights from an exploratory application on Samothraki (Greece). Fresenius Environ. Bull. 2014, 23, 1173-1182.

19. Skoulikidis, N. The uniqueness of Samothraki Island's environment. In Proceedings of the Sustainable Mediterranean, Summer University of Samothraki 2016: Integrated Management Approaches for Biosphere Reserves and other Designated Areas, Samothraki Island, Greece, 9-22 July 2016; pp. 17-19.

20. Syrides, G.; Vouvalidis, K.; Albanakis, K.; Tsourlos, P.; Matsas, D. Palaeogeographical Evolution and Sea Level Changes during Holocene in the Prehistoric Settlement of Mikro Vouni (Samothrace Island, Greece). Z. Geomorphol. Suppl. Issues 2009, 53, 39-54. [CrossRef]

21. RBMP. 1st Management Project Review of Thrace Hydrological District (EL12). In Preliminary River Basin Management Plan, 3rd ed.; Ministry of Environment \& Energy, Special Secretariat for Water: Merida, Mexico, 2017. [CrossRef]

22. Romaidis, I.; Favas, N. Hydrogeological study. In Water District of Thraki; IGME: Xanthi, Greece, 2010.

23. Panagopoulos, Y.; Dimitriou, E.; Skoulikidis, N. Vulnerability of a Northeast Mediterranean Island to Soil Loss. Can Grazing Management Mitigate Erosion? Water 2019, 11, 1491. [CrossRef]

24. Karavitis, C.A.; Kerkides, P. Estimation of the Water Resources Potential in the Island System of the Aegean Archipelago, Greece. Water Int. 2002, 27, 243-254. [CrossRef]

25. Pavlidis, S.; Valkaniotis, S.; Kurcel, A.; Papathanasiou, Y.; Xatzipetrou, A. Neotectonic structure of Samothraki Island in relation to the North Anatolia fault. Bull. Greek Geol. Soc. 2005, 37, 19-28.

26. Tsikouras, V.; Hatzipanagiotou, K. Geological evolution of Samothraki Island (N. Aegean, Greece): An incomplete ophiolitic sequence in the Circum-Rhodope Zone. Geol. Soc. Greece Sp. Publ. 1995, 4, 116-126.

27. Vergis, S. Hydrogeological Research of Samothraki Island; Institute of Geology and Mineral Exploration (IGME): Xanthi, Greece, 1984; p. 13.

28. Vergis, S. Hydrological Investigation of Samothraki Island; Institute of Geology and Mineral Exploration (IGME): Xanthi, Greece, 1986; p. 17.

29. Vlami, V.; Zogaris, S.; Djuma, H.; Kokkoris, I.P.; Kehayias, G.; Dimopoulos, P. A Field Method for Landscape Conservation Surveying: The Landscape Assessment Protocol (LAP). Sustainability 2019, 11, 2019. [CrossRef]

30. Biel, B.; Tan, K. The flora of Samothraki; Goulandris Natural History Museum: Kifissia, Greece, 2014; p. 228.

31. Korakis, Y.; Vidakis, K. The Aromatic and the Rapeutical Flora of Samothraki Island; Democritus University of Thrace, School of Agriculture and Forestry, Dept. of Forestry and Environmental and Natural resources Management: Thrace, Greece, 2018; p. 143.

32. Municipality of Samothraki. Samothraki Biosphere Reserve Nomination. Final Official Document-Resubmission; Institute of Social Ecology, Alpen-Adria University of Vienna; Municipality of Samothraki: Vienna, Austria; Samothraki, Greece, 2013.

33. Ministry of Aegean. List of Geological Monuments; Ministry of Aegean: Lesvos, Greece, 2000; 17, ISBN 960-7859-41-3.

34. European Environment Agency (EEA). Corine Land Cover 2006 Raster Data. Available online: https: //www.eea.europa.eu/data-and-maps/data/clc-2006-raster-4 (accessed on 8 July 2019). 
35. Municipality of Samothraki. Operational Program 2014-19; Municipality of Samothraki: Samothraki, Greece, 2020; p. 311.

36. Fischer-Kowalski, M.; Xenidis, L.; Singh, S.J.; Pallua, I. Transforming the Greek Island of Samothraki into a UNESCO Biosphere Reserve. An Experience in Transdisciplinarity. GAIA Ecol. Perspect. Sci. Soc. 2011, 20, 181-190. [CrossRef]

37. Fetzel, T.; Petridis, P.; Noll, D.; Singh, S.J.; Fischer-Kowalski, M. Reaching a socio-ecological tipping point: Overgrazing on the Greek island of Samothraki and the role of European agricultural policies. Land Use Policy 2018, 76, 21-28. [CrossRef]

38. Lampou, A. Assessment of the Ecological Water Quality, According to the Directive 2000/60/EC. in Rivers of Samothraki Island in 2011. Master's Thesis, Aristotle University of Thessaloniki, Thessaloniki, Greek, 2012.

39. Raven, P.; Holmes, N.; Dawson, F.; Everard, M. Quality assessment using River Habitat Survey data. Aquat. Conserv. Mar. Freshw. Ecosyst. 1998, 8, 477-499. [CrossRef]

40. Rantz, S.E. Measurement and Computation of Streamflow: Vol. 1, Measurement of Stage and Discharge; USGS Publications Warehouse; United States Government Printing Office: Washington, DC, USA, 1982; p. 284. [CrossRef]

41. Wentworth, C.K. A scale of grade and class terms for clastic sediments. J. Geol. 1992, 30, 377-392. [CrossRef]

42. Koroleff, F. Revised version of direct determination of ammonia in natural waters as indophenol blue. In Information on techniques and methodsfor the sea water analysis; ICES, C.M.: Copenhagen, Denmark, 1970; pp. 19-22, Interlab. Rep. No.3.

43. Shinn, M.B. A colorimetric method for the determination of nitrite. Ind. Eng. Chem. 1941, 13, $33-35$.

44. Strickland, J.D.H.; Parsons, T.R. A practical handbook of the sea water analysis. Bull. Fish. Res. Bd. Can. 1968, 167, 310.

45. Murphy, J.; Riley, J. A modified single solution method for the determination of phosphate in natural waters. Anal. Chim. Acta 1962, 27, 31-36. [CrossRef]

46. Environmental Systems Research Institute (ESRI). ArcGIS Desktop: Release 10, Redlands; Environmental Systems Research Institute: Realands, CA, USA, 2011.

47. Skoulikidis, N.T. Defining chemical status of a temporary Mediterranean River. J. Environ. Monit. 2008, 10, 842. [CrossRef]

48. Mann, H.B.; Whitney, D.R. On a Test of Whether one of Two Random Variables is Stochastically Langer than the Other. Ann. Math. Statist. 1984, 18, 50-60. [CrossRef]

49. Quinn, G.P.; Keough, M.J. Experimental Design and Data Analysis for Biologists; Cambridge University Press (CUP): Cambridge, UK, 2002.

50. SPSS Inc. PASW Statistics for Windows, Version 18.0; SPSS Inc.: Chicago, IL, USA, 2009.

51. Gaillardet, J.; Dupre, B.; Louvat, P.; Allègre, C. Global silicate weathering and $\mathrm{CO}_{2}$ consumption rates deduced from the chemistry of large rivers. Chem. Geol. 1999, 159, 3-30. [CrossRef]

52. Clarke, K.R.; Warwick, R.M. Similarity-based testing for community pattern: The two-way layout with no replication. Mar. Boil. 1994, 118, 167-176. [CrossRef]

53. Clarke, K.R.; Gorley, R.N. PRIMER v6: User Manual/Tutorial (Plymouth Routines in Multivariate Ecological Research); PRIMER-E: Plymouth, UK, 2006.

54. Levene, H. Robust testes for equality of variances. In Contributions to Probability and Statistics; Olkin, I., Ed.; Stanford University Press: Palo Alto, CA, USA, 1960; pp. 278-292.

55. Dimitriou, E.; Stavroulaki, E. Assessment of Riverine Morphology and Habitat Regime Using Unmanned Aerial Vehicles in a Mediterranean Environment. Pure Appl. Geophys. 2018, 175, 3247-3261. [CrossRef]

56. Whipple, K.; DiBiase, R.; Crosby, B. 9.28 Bedrock Rivers. In Treatise on Geomorphology; Elsevier BV: Amsterdam, The Netherlands, 2013; Volume 9, pp. 550-573.

57. Skoulikidis, N.; Lampou, A.; Katopodis, G. Water Metabolism and Water Management in Samothraki Island. In Final Report. Surface and Ground Water Quantities, Water Abstraction, Water Demand and a Preliminary Water Resources Management Plan; Institute of Marine Biological resources and Inland Waters: Anavyssos, Attika, Greece, 2019; p. 38.

58. Güler, C.; Thyne, G.D.; McCray, J.E.; Turner, K.A. Evaluation of graphical and multivariate statistical methods for classification of water chemistry data. Hydrogeol. J. 2002, 10, 455-474. [CrossRef]

59. Gordon, N.D.; McMahon, T.A.; Finlayson, B.L.; Gippel, C.L.; Nathan, R.J. Stream Hydrology. In $A n$ Introduction for Ecologists, 2nd ed.; John Wiley \& Sons Ltd.: London, UK, 2004; p. 431. 
60. Karalis, S.; Karymbalis, E.; Valkanou, K.; Chalkias, C.; Katsafados, P.; Kalogeropoulos, K.; Batzakis, V.; Bofilios, A. Assessment of the Relationships among Catchments' Morphometric Parameters and Hydrologic Indices. Int. J. Geosci. 2014, 5, 1571-1583. [CrossRef]

61. Naiman, R.J.; Décamps, H.; McClain, M.E.; Likens, G.E. Catchments and the Physical Template. In Riparia: Ecology, Conservation and Management of Streamside Communities; Naiman, R.J., Decamps, H., McClain, M.E., Likens, G.E., Eds.; Elsevier Academic Press: London, 2005; pp. 19-48.

62. Carlston, C.W. Drainage density and streamflow. In Professional Paper; US Geological Survey: Reston, VI, USA, 1963; pp. C1-C8.

63. Skoulikidis, N.T.; Zogaris, S.; Economou, A.N.; Gritzalis, K.C. Rivers of the Balkans; Elsevier BV: Amsterdam, The Netherlands, 2009; pp. 421-466. [CrossRef]

64. Wilson, J.L.; Guan, H. Mountain-Block Hydrology and Mountain-Front Recharge; American Geophysical Union (AGU): Washington, DC, USA, 2004; Volume 9, pp. 113-137. [CrossRef]

65. Lovett, G.M.; Reiners, W.A.; Olson, R.K. Cloud Droplet Deposition in Subalpine Balsam Fir Forests: Hydrological and Chemical Inputs. Science 1982, 218, 1303-1304. [CrossRef]

66. De Jong, C. The contribution of condensation to the water cycle under high-mountain conditions. Hydrol. Process. 2005, 19, 2419-2435. [CrossRef]

67. Scholl, M.; Eugster, W.; Burkard, R. Understanding the role of fog in forest hydrology: Stable isotopes as tools for determining input and partitioning of cloud water in montane forests. Trop. Montane Cloud For. 2011, 25, 228-241. [CrossRef]

68. Gassama, N.; Violette, S. Geochemical study of surface waters in mountain granitic area. The Iskar upper watershed: Massif of Rila, Bulgaria. Water Res. 1997, 31, 767-776. [CrossRef]

69. Merck, E. Die Untersuchung von Wasser, 9th ed.; Merck, E., Ed.; Witzenhausen: Berlin, Germany, 1975; p. 226.

70. Meybeck, M. River water quality Global ranges, time and space variabilities, proposal for some redefinitions. Ver. Internat. Verein. Limnol. 1996, 26, 81-96. [CrossRef]

71. Garrels, R.M.; Mackenzie, F.T. The Evolution of Sedimentary Rocks; W. W. Norton: New York, NY, USA, 1971; p. 397.

72. Meybeck, M. Pathways of major elements from land to ocean through rivers. In River Inputs to Ocean Systems; Martin, J.M., Burton, J.B., Eisma, D., Eds.; UNEP; IOC; SCOR: Rome, Italy, 1979; pp. 26-30.

73. Drever, J.I. The Geochemistry of Natural Waters, 2nd ed.; Prentice Hall: Englewood Cliff, NJ, USA, $1988 ;$ p. 437.

74. Bricker, O.P.; Rice, K.C. Acid deposition to streams; a geology based method predicts their sensitivity. Environ. Sci. Technol. 1989, 23, 379-385. [CrossRef]

75. Olson, J.R. The Influence of Geology and Other Environmental Factors on Stream Water Chemistry and Benthic Invertebrate Assemblages. In All Graduate Theses and Dissertations 1327; Utah State University: Logan, UT, USA, 2012.

76. Stober, I.; Teiber, H.; Li, X.; Jendryszczyk, N.; Bucher, K. Chemical composition of surface- and groundwater in fast-weathering silicate rocks in the Seiland Igneous Province, North Norway. Nor. J. Geol. 2017, 97, $63-93$. [CrossRef]

77. Dupré, B.; Dessert, C.; Oliva, P.; Goddéris, Y.; Viers, J.; François, L.; Millot, R.; Gaillardet, J. Rivers, chemical weathering and Earth's climate. C. R. Geosci. 2003, 335, 1141-1160. [CrossRef]

78. Heimann, K.O.; Lebkuchner, H.; Kretzler, W. Geological map of Greece. In Samothraki Sheet, Scale 1:50,000-Athens; Institute of Geology and Mineral Exploration: Athens, Greece, 1972.

79. Horton, T.; Chamberlain, C.P.; Fantle, M.; Blum, J.D. Chemical weathering and lithologic controls of water chemistry in a high-elevation river system: Clark's Fork of the Yellowstone River, Wyoming and Montana. Water Resour. Res. 1999, 35, 1643-1655. [CrossRef]

80. Likens, G.E.; Driscoll, C.T.; Buso, D.C. Long-Term Effects of Acid Rain: Response and Recovery of a Forest Ecosystem. Science 1996, 272, 244-246. [CrossRef]

81. Neal, C.; Kirchner, J.W. Sodium and chloride levels in rainfall, mist, streamwater and groundwater at the Plynlimon catchments, mid-Wales: Inferences on hydrological and chemical controls. Hydrol. Earth Syst. Sci. 2000, 4, 295-310. [CrossRef]

82. Keene, W.C.; Pszenny, A.A.P.; Galloway, J.N.; Hawley, M.E. Sea-salt corrections and interpretation of constituent ratios in marine precipitation. J. Geophys. Res. Space Phys. 1986, 91, 6647. [CrossRef]

83. Moeller, $\mathrm{D}$. The $\mathrm{Na} / \mathrm{Cl}$ ratio in rainwater and the seasalt chloride cycle. Tellus B Chem. Physical Meteorol. 1990, 42, 254-262. [CrossRef] 
84. Mihalopoulos, N.; Stephanou, E.; Kanakidou, M.; Pilitsidis, S.; Bousquet, P. Tropospheric aerosol ionic composition in the Eastern Mediterranean region. Tellus B Chem. Phys. Meteorol. 1997, 49, 314-326. [CrossRef]

85. Dollard, G.J.; Unsworth, M.H.; Harve, M.J. Pollutant transfer in upland regions by occult precipitation. Nature 1983, 302, 241-243. [CrossRef]

86. Neal, C.; Reynolds, B.; Neal, M.; Hill, L.; Wickham, H.; Pugh, B. Nitrogen in rainfall, cloud water, throughfall, stemflow, stream water and groundwater for the Plynlimon catchments of mid-Wales. Sci. Total. Environ. 2003, 314, 121-151. [CrossRef]

87. Budhavant, K.; Rao, P.; Safai, P.; Granat, L.; Rodhe, H. Chemical composition of the inorganic fraction of cloud-water at a high altitude station in West India. Atmos. Environ. 2014, 88, 59-65. [CrossRef]

(C) 2020 by the authors. Licensee MDPI, Basel, Switzerland. This article is an open access article distributed under the terms and conditions of the Creative Commons Attribution (CC BY) license (http://creativecommons.org/licenses/by/4.0/). 